
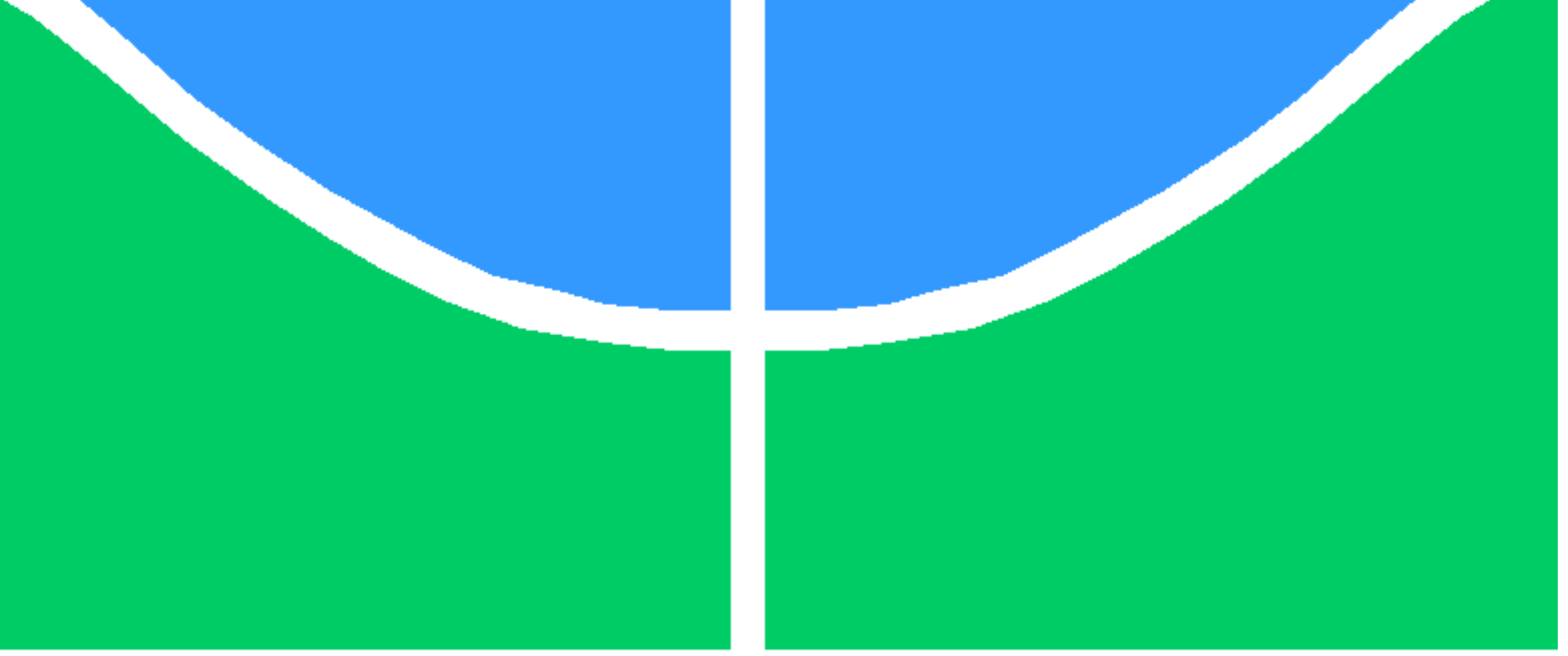

TRABALHO DE CONCLUSÃO DE CURSO

\title{
ESTUDO DE CÓDIGOS NÃO COERENTES PARA SISTEMAS MIMO/OFDM APLICADOS AO ENLACE DIRETO DO LTE
}

Rafhael Medeiros de Amorim 
Faculdade de Tecnologia

\title{
TRABALHO DE CONCLUSÃO DE CURSO \\ ESTUDO DE CÓDIGOS NÃO COERENTES \\ PARA SISTEMAS MIMO/OFDM APLICADOS AO ENLACE DIRETO DO LTE
}

\author{
Rafhael Medeiros de Amorim \\ Relatório submetido ao Departamento de Engenharia \\ Elétrica como requisito parcial para obtenção \\ do grau de Engenheiro Eletricista
}

Banca Examinadora

Prof. Dr. Paulo Henrique Portela de Carvalho,

$\mathrm{ENE} / \mathrm{UnB}$

Orientador

Prof. Dr. Robson Domingos Vieira, INdT

Orientador

Prof. Dr. Leonardo R. A. X. de Menezes,

$\mathrm{ENE} / \mathrm{UNB}$

Examinador interno

Prof. Dr. Leonardo Aguayo, INdT

Examinador externo

João Paulo Leite

Engenheiro de Redes de Comunicação 


\section{Dedicatória}

A Deus, por tudo o que me permitiu construir e a todos aqueles que de alguma forma fizeram parte da minha caminhada.

Rafhael Medeiros de Amorim 


\section{Agradecimentos}

Em primeiro lugar, a Deus, pelos passos firmes que foram dados quando a estrada parecia instável.

Aos meus pais pelo amparo e compreensão, pelos conselhos sábios e, sobretudo, pelo exemplo incessante durante toda a jornada.

Aos meus amigos por todas as alegrias que desfrutei nesses últimos anos; por todos os momentos divertidos que se equilibraram à seriedade exigida ao longo desses anos.

Rafhael Medeiros de Amorim 
Este trabalho analisa o comportamento de códigos não coerentes - aqueles no qual o receptor faz a demodulação do símbolo recebido sem estimações do canal físico - para sistemas MIMO/OFDM baseados em técnicas de agrupamento de subportadoras aplicadas ao enlace direto do 3G-LTE. A proposta deste trabalho é verificar o desempenho destes códigos em diferentes cenários e fazer uma comparação com alguns códigos coerentes elencando os custos e benefícios de cada escolha. Utilizando como plano de fundo para esta comparação o enlace direto do LTE (Long Term Evolution - proposta de evolução de longo termo do 3GPP para a terceira geração da rede UMTS ) as análises contidas no presente trabalho foram feitas a partir de resultados obtidos por meio de um simulador a nível de enlace desenvolvido dentro do projeto WiSiL que atende às especificações dessa tecnologia.

\begin{abstract}
This paper analyzes the behavior of group-based noncoherent codes - those which are demodulated at receiver without CSI (Channel State Information) - proposed to MIMO-OFDM systems applied to 3G-LTE downlink. The proposal of this work is to examine the performance of these codes in different scenarios and to make a comparison with some coherent codes listing the costs and benefits of each choice. Using as background the LTE (Long Term Evolution, proposed by 3GPPP, to the UMTS third generation) downlink the analysis presented here are performed from results obtained trough a link level simulator developed at WiSiL project which attends the specifications about this technology.
\end{abstract}




\section{SUMÁRIO}

$1 \quad$ Introdu

1.1 Estado Da ARTE ....................................................... 1

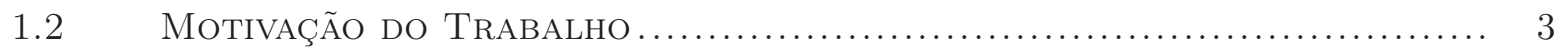

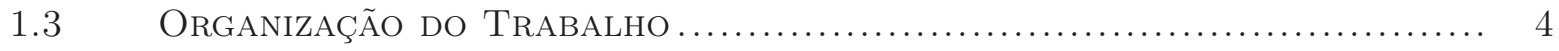

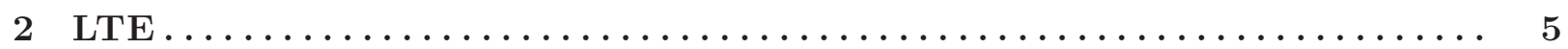

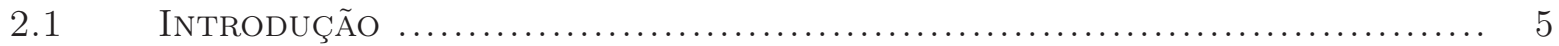

2.2 Camada Física no Enlace Direto ...................................... 6

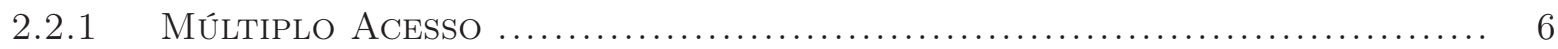

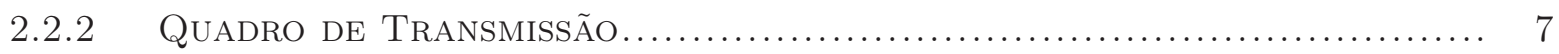

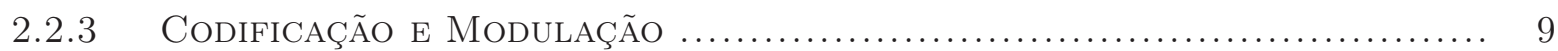

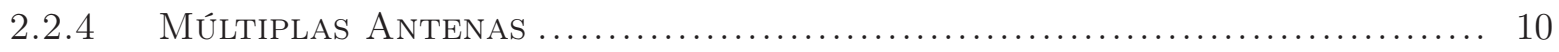

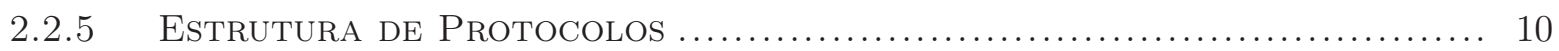

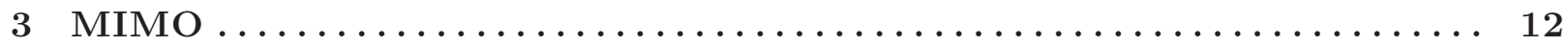

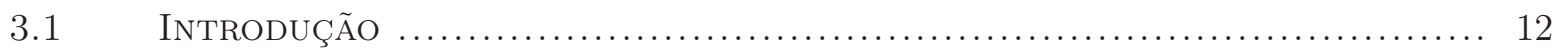

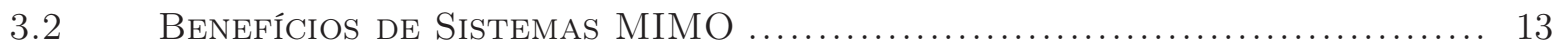

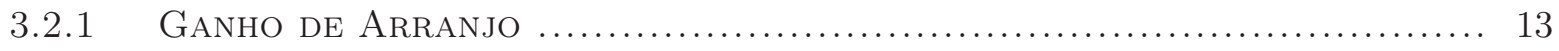

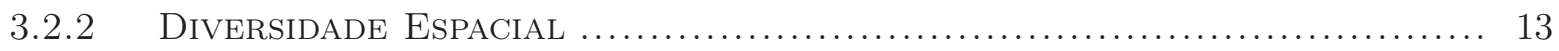

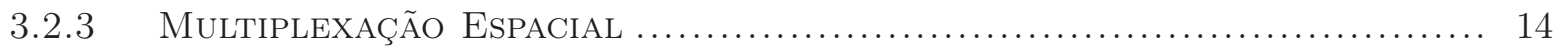

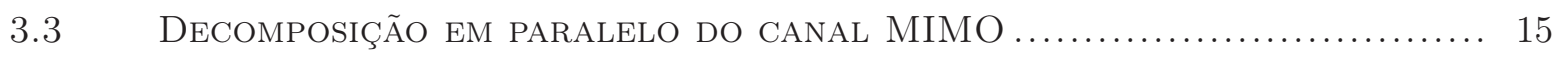

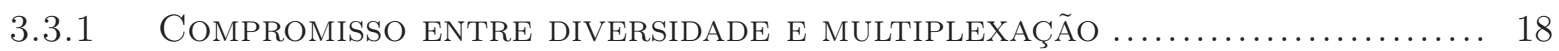

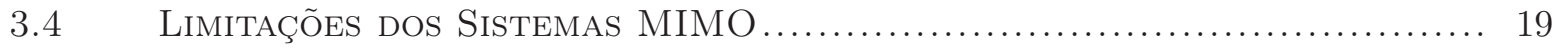

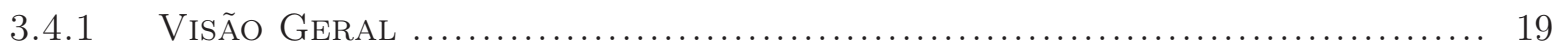

3.4.2 Resultados Comparativos ............................................. 20

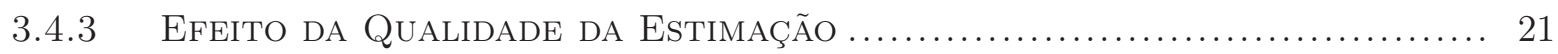

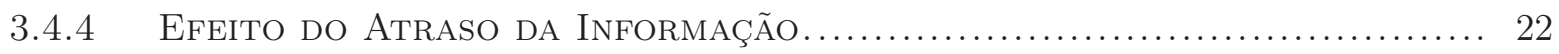

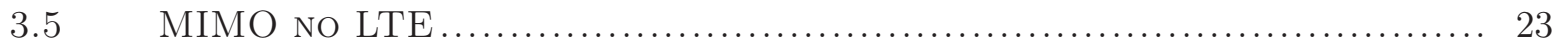

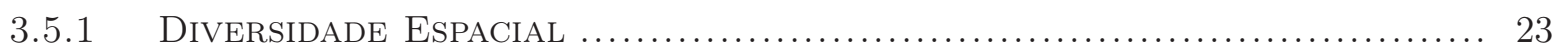

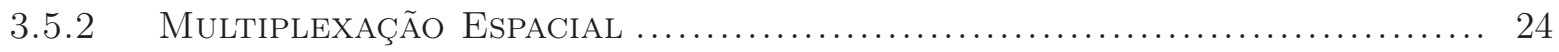

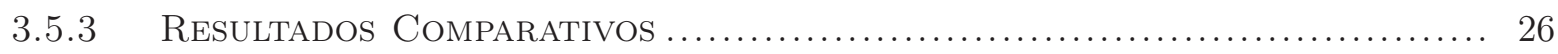

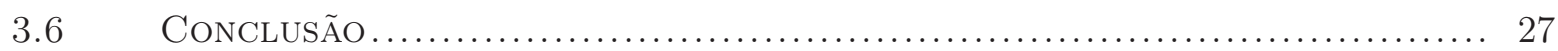

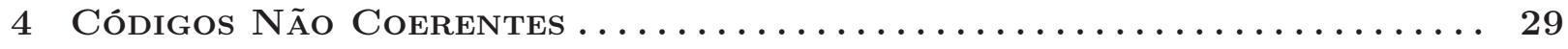




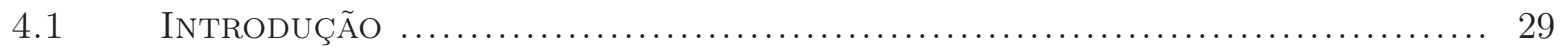

4.2 Código não Coerente Puro ...................................... 30

4.2.1 CodificaÇão NCP BASEAdo EM Grupos de SubPortadoras ............... 32

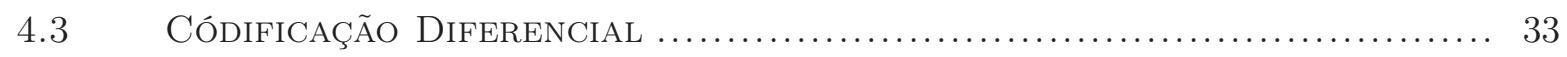

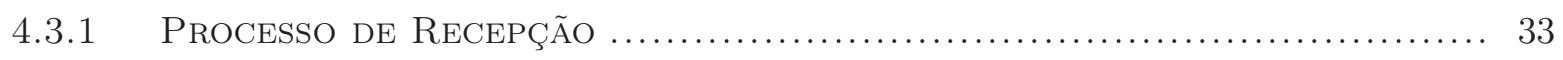

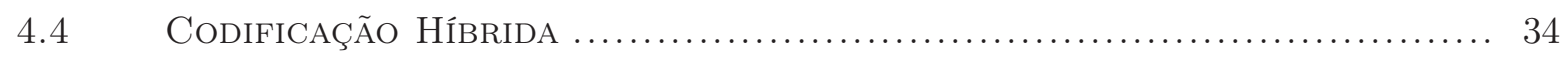

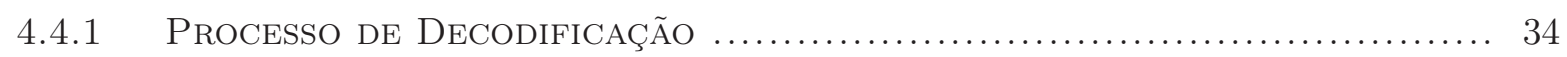

4.5 Resultados de Simulą̧ão e Análise dos Códigos ....................... 35

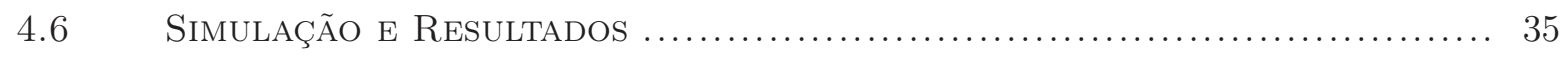

4.7 Comparação entre Códigos Coerentes e não Coerentes ............... 39

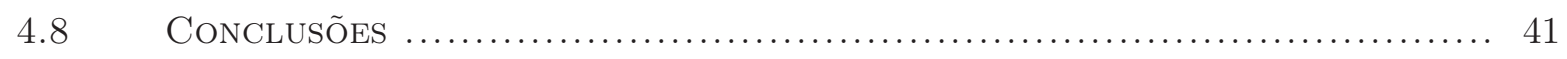

5 Conclusões e Sugestões para Trabalhos Futuros $\ldots \ldots \ldots \ldots \ldots \ldots \ldots$

REFERÊNCIAS BIBLIOGRÁFICAS $\ldots \ldots \ldots \ldots \ldots \ldots \ldots \ldots \ldots \ldots \ldots$

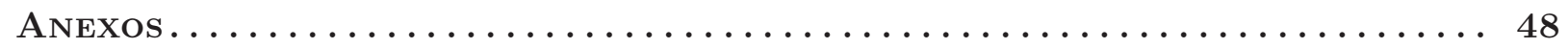




\section{LISTA DE FIGURAS}

2.1 Estrutura do quadro de transmissão do LTE para o esquema FDD $\ldots \ldots \ldots \ldots \ldots \ldots \ldots \ldots . \quad 7$

2.2 Estrutura do quadro de transmissão do LTE para o esquema TDD $\ldots \ldots \ldots \ldots \ldots \ldots \ldots \ldots . \quad 8$

2.3 Detalhamento do slot do LTE para o enlace direto ............................... 9

2.4 Estrutura de protocolos para o enlace direto do LTE (simplificada). ................. 11

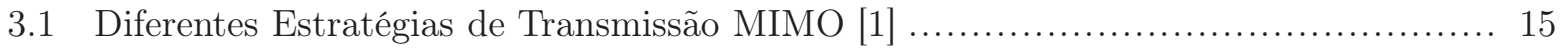

3.2 Modelo Simplificado de um Sistema MIMO [2] .................................. 15

3.3 Processamento do sinal no transmissor e receptor para decomposição do canal MIMO

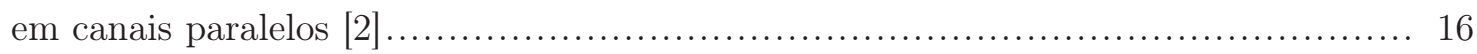

3.4 Decomposição em Paralelo do Canal MIMO [3] ................................. 17

3.5 Formação de Feixe em um Canal MIMO para diversidade espacial. [3] ................ 18

3.6 Gráfico de compromisso entre os graus de diversidade e multiplexação espacial ....... 19

3.7 Fluxograma de Simulação do WiSiL ......................................... 21

3.8 Comparação entre estimadores para diagonalização do canal MIMO .................. 22

3.9 Efeito dda velocidade do móvel na diagonalização do Sistema MIMO ................. 23

3.10 Efeito do atraso na estimação do canal para a diagonalização do Sistema MIMO..... 24

3.11 Fluxo da informação para transmissão em múltiplas antenas no LTE. [16] ............ 24

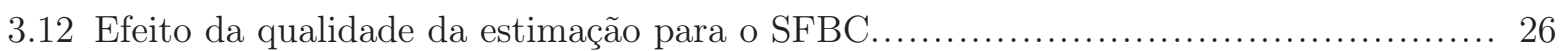

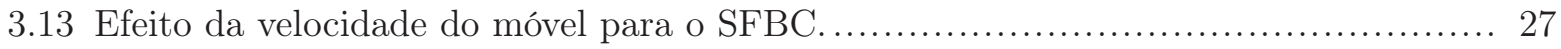

4.1 Rotação de fase aplicada sobre os coeficientes de $\mathbf{H}_{l}$ para o desvio de frequência de cada subportadora OFDM e ao instante de chegada $\psi_{l} \ldots \ldots \ldots \ldots \ldots \ldots \ldots \ldots \ldots \ldots \ldots \ldots \ldots$

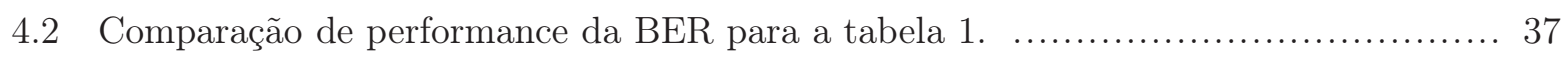

4.3 Comparação da performance da BER para o código 2 em diferentes cenários .......... 38

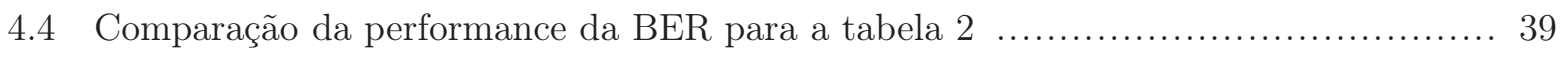

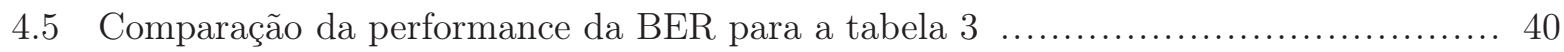

4.6 Comparação da performance da BER para a Tabela 4 ........................... 41 


\section{LISTA DE TABELAS}

2.1 Número de subportadoras OFDM para o enlace direto do LTE $\ldots \ldots \ldots \ldots \ldots \ldots \ldots \ldots \ldots . \quad 8$

2.2 Número de símbolos OFDM por slot para o enlace direto do LTE ................... 9

3.1 Cenário de Simulação para o canal MIMO decomposto em canais paralelos ........... 21

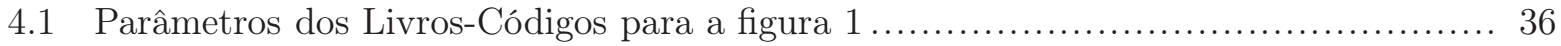

4.2 Parâmetros dos Livros-Códigos para a codificação Diferencial ........................ 38

4.3 Parâmetros dos Livros-Códigos para a técnica híbrida ............................ 39 


\title{
LISTA DE SÍMBOLOS
}

\author{
16-QAM 16 Quadrature Amplitude Modulation \\ 3GPP Third Generation Partnership Project \\ 3G Terceira Geração de Sistemas de Telecomunicações Móveis \\ 4G Quarta Geração de Sistemas de Telecomunicações Móveis \\ 64-QAM 64 Quadrature Amplitude Modulation \\ ANATEL Agência Nacional de Telecomunicações \\ ARQ Automatic Repeat Query \\ BER Bit Error Rate \\ CSI Channel State Information \\ FDD Frequency Division Duplex \\ FFT Fast Fourier Transform \\ FSTD Frequency Shift Transmit Diversity \\ GLRT Generalized Likelihood Ratio Test \\ GSM Global System for Mobile Communications \\ HARQ Hybrid Automatic Repeat Query \\ HSDPA High Speed Downlink Packet Access \\ HSPA High Speed Packet Access \\ HSUPA High Speed Uplink Packet Access \\ IMT- International Mobile Telecommunications-Advanced
}

Advanced

INdT Instituto Nokia de Tecnologia

ITU-R International Telecommunications Union - Radiocommunication Sector

LTE Long Term Evolution

LTE-A Long Term Evolution-Advanced

ou LTE-

Advanced

MAC Medium Acess Control

MIMO Multiple-Input Multiple-Output

MISO Multiple-Input Single-Output

ML Maximum Likelihood

MMSE Minimum Mean Squared-Error

NCP Código Não Coerente Puro

NCPG Código Não Coerente Puro baseado em técnica de Grupos

OFDM Orthogonal Frequency Division Multiplexing

OFDMA Orthogonal Frequency Division Multiple Access

PAPR Peak-to-Average Power Ratio

PHY Physical Layer

PRB Physical Resource Block

QPSK Quadrature Phase-Shift Keying 


\section{Capítulo 1}

\section{Introdução}

\subsection{Estado da Arte}

Nos últimos anos, os serviços de comunicação móvel experimentaram, em todo o globo, uma grande expansão em seus mercados, atingindo parcelas significativas da população. Para se ter uma idéia, em abril de 2009, a Agência Nacional de Telecomunicações (ANATEL) divulgou um balanço no qual se estima em mais de 150 milhões o número de usuários do Serviço Móvel Pessoal (SMP) no Brasil, o que corresponde a aproximadamente $80 \%$ da população nacional [4]. Além disso, com a evolução dos sistemas, surge uma nova demanda por serviços diferenciados, como por exemplo a possibilidade em acessar a Internet a partir de um terminal móvel.

Para que as operadoras destes sistemas possam suprir o número crescente de usuários, oferecendo, cada vez mais, novos serviços e atendendo a certas requisições de qualidade, é necessário que a utilização do espectro eletromagnético se dê da forma mais eficiente possível, uma vez que este é um recurso escasso. Muitas pesquisas têm sido feitas na direção de melhorar o aproveitamento do espectro, com recentes avanços significativos.

Na busca dessa evolução constante, existem fatores relevantes que não podem ser deixados de lado. Ao contrário das redes que utilizam cabos ou fibras para realizar a transmissão da informação, nos sistemas móveis, o espectro eletromagnético, meio de transmissão empregado, é compartilhado entre tecnologias diferentes e potencialmente interferentes. Por isso, órgãos regulatórios nacionais e regionais e órgãos padronizadores - em especial, a ITU-R (International Telecommunication Union - Radio Communication Sector - União Internacional de Telecomunicação - Setor de RádioComunicação ) - desempenham papel fundamental ao decidir quais bandas devem ser alocadas para cada diferente tipo de tecnologia. Dessa forma, definida a banda de operação para determinada tecnologia se viabiliza a padronização deste sistema, que por sua vez visa garantir um uso eficiente do espectro, mitigar a interferência entre tecnologias, além de permitir a interoperabilidade entre equipamentos de diversos fabricantes por meio de interfaces bem definidas.

Outro ponto relevante da padronização dos sistemas é a tentativa de realizar migrações suaves entre tecnologias, buscando o maior aproveitamento possível dos recursos de rede já instalados e, portanto, uma minimização dos custos de implementação da nova rede. 
Dentro deste contexto de inovação insere-se o LTE (Third Generation Long Term Evolution Evolução de Longo Termo para a Terceira Geração), proposto pelo 3GPP como uma evolução de longo prazo para os sistemas da terceira geração (3G) que busca manter a competitivade da linha evolutiva advinda do GSM, com uma interface de rádio altamente flexível [5].

O 3GPP é um grupo de estudos que iniciou suas atividades no ano de 1998, formado por um conjunto de empresas padronizadoras de regiões distintas do globo [6], com o intuito de alinhar o desenvolvimento paralelo das especificações, acelerando o progresso das inovações. No início, o 3GPP tinha como principal objetivo elaborar relatórios técnicos para as evoluções nas tecnologias empregadas no sistema GSM, exemplo o UTRA (Universal Terrestrial Radio Acess - Acesso de Rádio Terrestre Universal) [7].

Essa preocupação na evolução da rede para atender a expansão dos mercados de transmissão de dados pela telefonia celular levou a evoluções nas tecnologias empregadas com o surgimento do HSDPA (High Speed Downlink Packet Access - Acesso a Pacotes em Alta Velocidade para o Enlace Direto) e do HSUPA (High Speed Uplink Packet Access - Acesso a Pacotes em Alta Velocidade para o Enlace Reverso), formando o HSPA (High Speed Packet Access - Acesso a Pacotes em Alta Velocidade).

Porém, para continuar atendendo a demanda crescente de assinantes interessados na alta taxa de transmissão (entre 50 e 100 Mpbs) e manter-se em um nível competitivo frente às novas tecnologias do mercado, no ano de 2004, o 3GPP decidiu iniciar os estudos para uma evolução no longo prazo, dando o primeiro passo na direção de elaboração das normas que constituiriam o LTE. Desde as primeiras discussões sobre a nova tecnologia, foram traçadas metas ambiciosas de qualidade e eficiência da rede.

Para atingir as metas especificadas, o 3G-LTE propôs varias estratégias inovadoras para uma rede móvel. De fato, desde a primeira especificação divulgada o LTE já abordava diversas características originalmente consideradas para a quarta geração (4G) de redes móveis do futuro [8].

Entre várias dessas características inovadoras, O LTE foi o primeiro sistema celular de escala global a propor transmissões MIMO (Multiple-Input Multiple-Output - Múltiplas Entradas e Múltiplas Saídas), isto é, sistemas que utilizam múltiplas antenas no transmissor e no receptor como um de seus componentes chaves desde o princípio. Outra inovação do LTE em relação a sua linha evolutiva é a adoção do OFDM para realizar as técnicas de múltiplo acesso. As vantanges do OFDM estão na robustez à seletividade em frequência do canal e simplificação da arquitetura da rede que esta modulação permite.

Em 2008, com a criação do conceito de quarta geração IMT-Advanced, pela ITU-R, o 3GPP começou os estudos sobre a criação do LTE-Advanced (LTE-A), que busca atingir as características e especificações propostas para o 4G. Em junho do mesmo ano, o primeiro relatório técnico foi elaborado [9].

Entre as principais características da quarta geração, metas a serem alcançados pelo LTE-A, estão, um pico de taxas de transmissão elevados mesmo em alta mobilidade do terminal móvel (os objetivos correspondem a 1 Gbps para baixa mobilidade e 100 Mbps para alta mobilidade). 


\subsection{Motivação do Trabalho}

A intensa evolução tecnológica experimentada pelo mundo moderno tem acelerado deveras os processos produtivos em todo o mundo [3]. À luz dessa nova configuração, a informação passou a ser um bem valioso e a celeridade no seu fluxo imprescindível. A nova conjuntura exige que as redes celulares sejam capazes de suportar não só o tráfego de voz como também o de dados e em velocidade cada vez maior.

Os avanços nos sistemas de terceira geração (como é o caso do LTE) tem como objetivo corresponder a essa demanda global e, sendo o espectro finito e caro, a melhor forma de se obter taxas elevadas de transmissão é através de técnicas que permitam um aumento da eficiência espectral. Uma das estratégias adotadas para o LTE atingir maior eficiência é o uso de configurações multi-antena (MIMO).

A maioria das tecnologias modernas propõe esquemas MIMO para obter a partir dos múltiplos subenlaces gerados pela combinação das múltiplas antenas do receptor e do transmissor ganhos na eficiência do sistema.

Apesar de as tecnologias MIMO serem uma tendência atual, ainda restam algumas lacunas na busca de formas ótimas de se transmitir a informação, extraindo o ganho máximo das múltiplas antenas empregadas de maneira viável para o sistema.

Isso ocorre porque, de uma maneira geral, o desempenho dos esquemas MIMO está intrinsecamente relacionado com a precisão da estimação do canal. Entretanto, proceder essa estimação, principalmente em ambientes com desvanecimento rápido seletivo em frequência, pode ser computacionalmente custoso para o sistema, especialmente quando se opera em múltiplas antenas. $\mathrm{O}$ principal empecilho em se ter grande custo computacional na recepção encontra-se do lado do terminal móvel. Não só o atraso gerado pelo tempo gasto com cálculos necessários à estimação podem ser prejudiciais na recuperação da informação, como a miniaturização do terminal e o consumo de bateria podem ser comprometidos. Além disso, nem sempre os parâmetros do canal necessários para a correta estimação podem ser aferidos, mesmo no lado do receptor [10].

Ademais, é necessário, entre outras coisas, que símbolos pilotos sejam enviados de tempos em tempos dentro do quadro transmitido para realizar a estimação do canal. Estes pilotos usam recursos que poderiam carregar informação líquida, mas é perdido em função da estimação do canal. Assim, recai-se em uma relação de compromisso: quão maior for o número de pilotos, mais recursos de informação útil são cedidos em função da estimação; a diminuição do número de pilotos, todavia, acarreta em uma pior aproximação do canal físico.

Considerando-se as metas ambiciosas de longo prazo estabelecidas para o LTE-Advanced, os problemas da estimação do canal MIMO passa a ser um obstáculo que necessita ser contornado. Os esquemas MIMO mostram-se como uma das principais técnicas que podem auxiliar as próximas gerações de sistemas móveis a atingir as taxas elevadas propostas (até 1 Gbps no enlace direto para baixa mobilidade), contudo o LTE-A propõe que os sistemas sejam capazes de fornecer taxas elevadas de transmissão memso para usuários com alta mobilidade (100 Mbps de pico).

Entretanto, para usuários em altas velocidades, os efeitos dispersivos do canal passam a variar 
rapidamente com o tempo, o que dificulta o processo de estimação do canal. Para lidar com esse tipo de situação as técnicas coerentes necessitam que uma maior quantidade de pilotos seja enviada para melhorar a acurácia do canal estimado. Por outro lado, o acréscimo no número de pilotos significa redução da eficiência espectral do sistema, uma vez que estes usam parte dos recursos da rede.

Com a camada física do LTE já definida e com o início dos estudos sobre o LTE-A, a tendência é propor alterações que devem ser feitas na camada física para atingir os objetivos propostos.

Técnicas de transmissão não coerentes propõem métodos de se efetuar a transmissão em esquemas MIMO sem realizar a estimação dos efeitos da propagação do sinal. Existe, nesse caso, um compromisso entre perda na taxa de erro de bit (BER) do sistema - pela completa ausência de informação sobre o canal - pela diminuição da complexidade do receptor e eliminação da necessidade do envio de pilotos.

O presente trabalho tem como objetivo avaliar o desempenho de alguns tipos de codificação não coerente aplicados ao enlace direto do LTE e, além de entender a influência dos parâmetros do sistema no desempenho do código, fazer considerações sobre os custos e os benefícios da adoção desses códigos.

\subsection{Organização do Trabalho}

O estudo proposto foi dividido em 4 capitulos. O Capítulo 2 descreve o LTE mostrando as inovações propostas por essa tecnologia e aborda diversos aspectos de sua camada física dando ênfase aos processos do enlace direto. No Capítulo 3 é desenvolvida a base teórica sobre transmissões em múltiplas antenas. Entre outras coisas são abordadas as vantagens dessa estratégia e são feitas considerações sobre suas limitações, principalmente no que concerne a necessidade de estimação do canal. O Capítulo 4 propõe códigos não coerentes e exibe os resultados de simulação para a aplicação destes no enlace direto do LTE. Por fim o Capítulo 5 apresenta as conclusões do presente estudo. 


\section{Capítulo 2}

\section{LTE}

Neste capítulo serão abordados alguns aspectos básicos que envolvem o LTE, enfatizando as operações no enlace direto.

\subsection{Introdução}

Nas últimas duas décadas, acompanhou-se a consolidação e uma intensa expansão no mercado dos serviços de comunicação móvel. Este fato deve-se, em grande parte, à evolução gradual das tecnologias empregadas, que permitiram uma diminuição de custo e um aumento na fiabilidade destas redes. Como consequência deste movimento observou-se o surgimento de novas possibilidades de serviços baseados no tráfego de dados, como por exemplo enviar ou receber arquivos e programas, e, com isso, a capacidade de atingir altas taxas de transmissão passou a ser um parâmetro de qualidade da rede para os usuários que desejam utilizar esses serviços.

Para que as operadoras destes sistemas possam suprir as exigências do mercado, sem comprometer a qualidade na prestação do serviço, é necessário que a utilização do espectro eletromagnético seja a mais eficiente possível. Este fato tem motivado uma série de estudos que visam à evolução das tecnologias aplicadas às redes de comunicação móvel. Enquanto, previsões já apontam para a implementação da quarta geração nos próximos anos, os estudos acabaram culminando na criação do sistema LTE como uma proposta de evolução de longo termo para os sistemas da terceira geração que traz características inovadoras e metas ambiciosas a serem atingidas.

Alguns requisitos de desempenho estão presentes desde as primeiras discussões sobre o LTE, como [11]:

- capacidade de fornecer altas taxas de transmissão ao usuário;

- custo de bit reduzido, como resultado de uma elevada eficiência espectral;

- arquitetura simplificada;

- flexibilidade e diversidade nos serviços oferecidos;

- reduzido consumo de energia do lado do terminal móvel.

Além disso, alguns objetivos de longo prazo foram traçados para o desenvolvimento do LTE [12], dos quais destacam-se: 
- alcançar picos de 100 Mbps na taxa de transmissão para o enlace direto (atualmente as redes HSDPA fornecem 14,4 Mbps);

- alcançar picos de 50 Mbps na taxa de transmissão para o enlace reverso (atualmente as redes HSUPA fornecem 5,7 Mbps);

- suporte para bandas de frequências de até $20 \mathrm{MHz}$ (com previsão de bandas menores para alocações mais estreitas: 1,4 MHz,5 MHz,10 MHz e $15 \mathrm{MHz}$ );

- redução significativa da latência da rede. No plano do usuário a latência deve ser inferior a $5 \mathrm{~ms}$ para bandas superiores a $5 \mathrm{MHz}$ e inferior a 10ms para bandas inferiores;

- aumentar a taxa de transmissão média por usuário em 2 vezes no enlace direto e 3 vezes no enlace reverso;

- aumentar a eficiência espectral por usuário em 2 vezes no enlace direto e 3 vezes no enlace reverso;

- dobrar a taxa de transmissão média por usuário localizado próximo às bordas da célula.

\subsection{Camada Física no Enlace Direto}

\subsubsection{Múltiplo Acesso}

A flexibilidade de serviços almejada pelos sistemas das futuras gerações traduz-se, muitas vezes, em flexibilidade das taxas disponibilizadas aos usuários. Em linhas gerais, o sistema deve ser capaz de fornecer taxas maiores ou menores conforme o serviço requerido. Para perceber este fato basta considerar que uma chamada de vídeo exige taxa de transmissão mais elevada que uma chamada de voz. Neste caso, se o sistema conferir uma taxa insuficiente para um usuário que realiza uma chamada de vídeo, haverá atraso na propagação da informação e a qualidade do serviço estará comprometida.

Por outro lado, se o sistema disponibilizar uma taxa muito elevada para um usuário efetuando uma chamade de voz, haverá subaproveitamento dos recursos do sistema que poderiam ser destinados a outros usuários. Baseado nisso, a técnica de múltiplo acesso escolhida pelo LTE deveria não só manter a simplicidade da arquitetura da rede como fornecer suporte a essa flexibilidade.

Em dezembro de 2005, o 3GPP escolheu as técnicas de múltiplo acesso que deveriam ser aplicadas ao LTE [3]. Na ocasião foram escolhidos: SC-FDMA (Single Carrier Frequency Division Multiple Access) para o enlace reverso e o OFDMA (Orthogonal Frequency Division Multiple Access) para o enlace direto.

A técnica OFDMA é realizada a partir de uma extensão da tecnologia OFDM: o OFDM divide a banda de transmissão em um grande número de subportadoras de banda estreita mutuamente ortogonais, onde cada uma delas é capaz de carregar informações independentes; o OFDMA distribui essas subportadoras entre múltiplos usuários. 
A escolha do OFDMA traz inúmeras vantagens ao sistema, entre elas destaca-se o fato de que cada usuário pode ter acesso a diferentes larguras de banda do sistema variando apenas o número de subportadoras alocadas, o que simplifica as interfaces do sistema. Além disso o OFDM tem as vantagens de ser robusto a canais seletivos em frequência e exigir baixa complexidade do equipamento receptor ao converter canais de banda larga dispersivos em vários canais de banda estreita [13].

Contudo, o transmissor OFDM é mais custoso, pois exige um amplificador de potência altamente linear para contornar os efeitos da PAPR (peak-to-average power ratio - Razão entre o pico e a média da potência), bastante elevados nesta técnica de transmissão [14], [15]. Como, em geral, limitações de custo são mais severas do lado do terminal móvel do que no lado da estação base, esta restrição acabou se mostrando contornável para o enlace direto, mas se torna um entrave para o enlace reverso. Combinados, esses fatores serviram como motivação para adoção do OFDMA no enlace direto do LTE.

\subsubsection{Quadro de Transmissão}

Conforme consta em [16], a norma do LTE prevê suporte para dois modos de duplexação o FDD (frequency division duplex) e o TDD (time division duplex). Em ambos os casos, o quadro de transmissão, com duração de $10 \mathrm{~ms}$, é dividido em subquadros - formados por conjuntos inteiros de símbolos OFDM - de igual duração. As estruturas dos subquadros podem variar dentro de um mesmo quadro para atender a diferentes exigências do sistema - em relação a tráfego e latência.

No modo FDD, as transmissões do enlace reverso e do enlace direto são separadas no domínio da frequência. Isto significa que há uma banda alocada para transmissão na direção estação baseterminal móvel e outra banda alocada para a direção terminal móvel-estação base. Para o FDD, o quadro de transmissão é dividido em 10 subquadros, cada um destes contendo 2 slots de duração $0,5 \mathrm{~ms}$, conforme mostra a Figura 2.1.

A operação no modo TDD divide o quadro de operação em 2 semiquadros de 5 ms, constituídos separadamente por 4 subquadros de 2 slots (com duração de $0.5 \mathrm{~ms}$ cada). Há ainda em cada subquadro um espaço de $1 \mathrm{~ms}$ reservado para campos especiais de transmissão, como pode ser visto na figura 2.2. No TDD cada subquadro pode ser reservado separadamente para o enlace direto, ou para o enlace reverso, de acordo com as necessidades da rede, conferindo certa flexibilidade ao sistema.

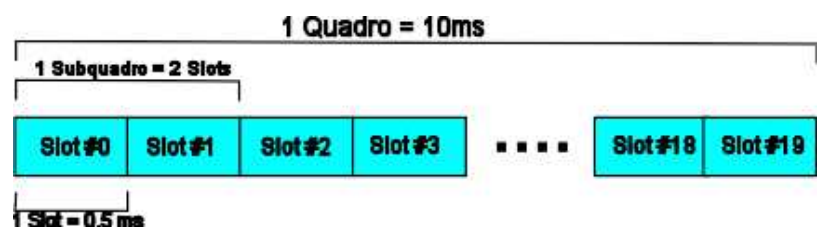

Figura 2.1: Estrutura do quadro de transmissão do LTE para o esquema FDD

Para o enlace direto do LTE, cada um dos slots dentro de um quadro de transmissão é composto por uma malha de $N_{c}$ subportadoras e por $N_{\text {symb }}$ símbolos OFDM, consoante mostra a figura 2.3. 


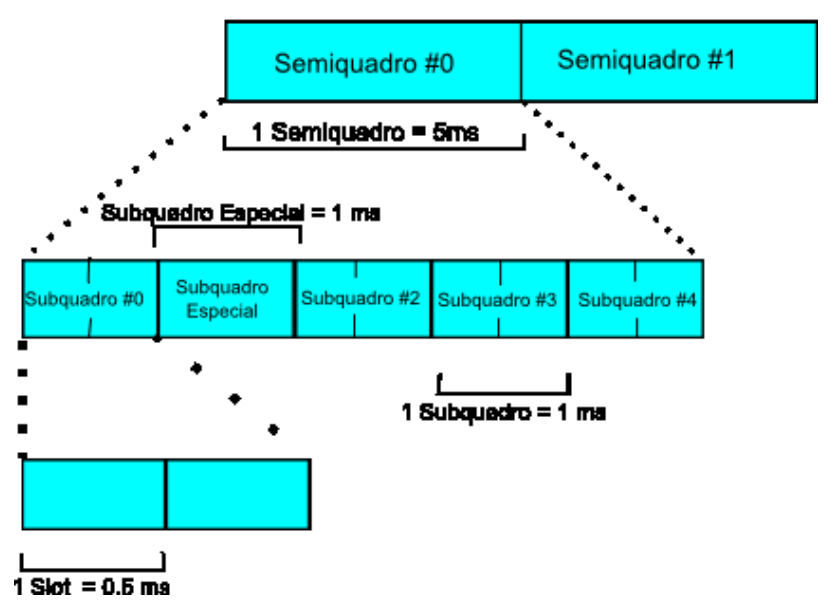

Figura 2.2: Estrutura do quadro de transmissão do LTE para o esquema TDD

O valor de $N_{c}$ é determinado a partir da banda de transmissão ${ }^{1}$ e $N_{\text {symb }}$ está instrinsecamente relacionado ao tamanho do prefixo cíclico do símbolo OFDM. Valores para $N_{c}$ e $N_{\text {symb }}$ prescritos pela padronização do LTE estão nas tabelas 2.1 e 2.2 .

Tabela 2.1: Número de subportadoras OFDM para o enlace direto do LTE

\begin{tabular}{|c|c|c|c|c|c|}
\hline Largura de Banda (MHz) & 1,4 & 5 & 10 & 15 & 20 \\
\hline$N_{c}$ & 72 & 300 & 600 & 900 & 1.200 \\
\hline
\end{tabular}

A menor unidade formadora desta malha, unicamente definida por uma subportadora alocada dentro de um símbolo OFDM, é chamada de elemento de recurso. Cada elemento de recurso é capaz de carregar um símbolo digital modulado de acordo com uma das técnicas previstas, sendo a menor unidade de transmissão do sistema.

Uma vez que a malha de recursos do LTE é dividida em 2 dimensões - tempo e frequência - a alocação de recursos aos usuários deve ser feita levando-se em conta ambas as dimensões. Define-se, então, um bloco de recursos físicos ou PRB (do inglês Physical Resource Block) como uma banda de $180 \mathrm{kHz}$ com duração de um slot de tempo, o que corresponde na prática a um conjunto de $N_{c}^{P R B}=12$ subportadoras contíguas e $N_{\text {symb }}$ símbolos OFDM consecutivos. O PRB é a unidade de recursos alocados para um dado usuário. A codificação e o esquema de modulação adotados podem variar de PRB para PRB adaptando-se às condições dos diferentes enlaces e à resposta em frequência do canal. A Figura 2.3 ilustra melhor o conceito de elemento de recurso e de bloco de recursos físicos.

\footnotetext{
${ }^{1} \mathrm{O}$ espaçamento padrão entre subportadoras adjacentes para o LTE é de $15 \mathrm{kHz}$.
} 
Tabela 2.2: Número de símbolos OFDM por slot para o enlace direto do LTE

\begin{tabular}{|c|c|}
\hline Configuração & $N_{\text {symb }}$ \\
\hline Prefixo Cíclico Normal $(4,69 \mu \mathrm{s})$ & 7 \\
\hline Prefixo Cíclico Extendido $(16,67 \mu \mathrm{s})$ & 6 \\
\hline
\end{tabular}

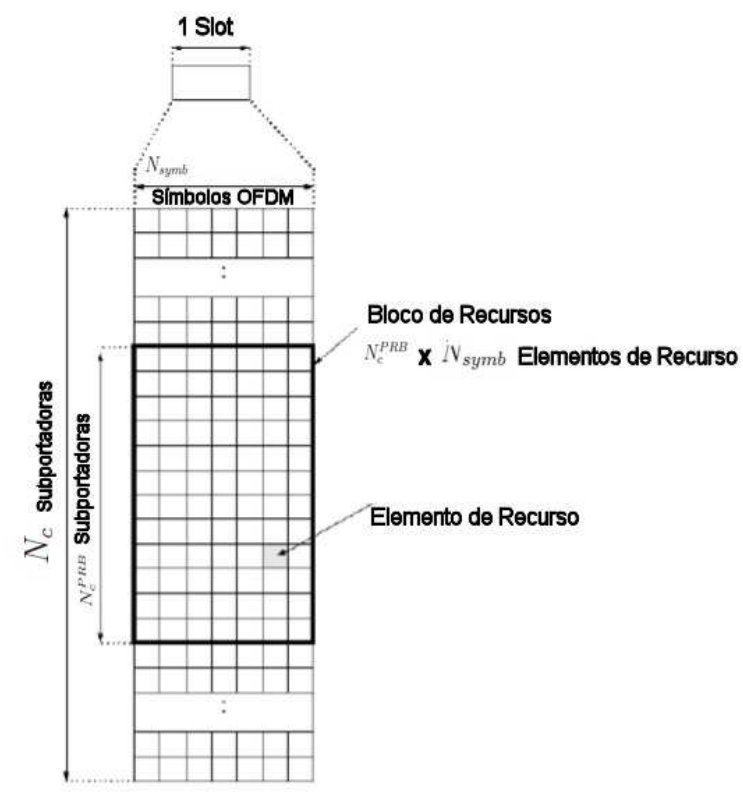

Figura 2.3: Detalhamento do slot do LTE para o enlace direto

\subsubsection{Codificação e Modulação}

O 3GPP prevê para o LTE a utilização de três esquemas de modulação digital para o enlace direto: QPSK, 16QAM ou 64 QAM [17]. A possibilidade de se ter diferentes modulações visa garantir flexibilidade na eficiência espectral e adaptabilidade ao ambiente de propagação do sinal. Em ambientes severos, é possível a escolha de uma modulação mais robusta e menos eficiente (QPSK, no caso mais robusto), enquanto em ambientes mais suaves pode-se escolher uma técnica de modulação de ordem superior e capaz de atingir maior eficiência espectral (64QAM, no melhor caso para a eficiência espectral).

A codificação de canal aplicada sobre os canais de transporte ${ }^{2}$ é a codificação turbo com taxa de 1/3. Capazes de prover palavras códigos longas com, relativamente, baixa complexidade no estágio de decodificação[18], os códigos turbos aprensentam desempenho próximo dos limites teóricos de Shannon [19, 20]. Esquemas de seleção e perfuração podem ser aplicados ao código turbo para atingir maior flexibilidade na taxa de código, de acordo com as exigências do sistema.

Há ainda previsão da utilização de mecanismos de repetição ARQ(Automatic Repeat Query) e HARQ (Hybrid Automatic Repeat Query) que combinados ao código turbo são capazes de prover diferentes taxas de codificação e interessantes soluções de compromisso entre considerável redução

\footnotetext{
${ }^{2}$ Informação líquida transmitida
} 
na taxa de erro e diminuição da eficiência espectral [21].

\subsubsection{Múltiplas Antenas}

Sistemas sem fio que adotam o uso de múltiplas antenas - tanto no transmissor como no receptor - são conhecidos por ter potencial para atingir eficiência espectral maior do que sistemas que utilizam apenas uma única antena em ambas as pontas [22]. Aplicações militares, já na década de 60, utilizavam os conceitos de conformação de feixe para obter ganhos na transmissão.

Visando o ganho oferecido pelo uso de múltiplos elementos transmissores/receptores, nos últimos anos, foram publicados inúmeros estudos que buscam formas mais eficientes de se utilizar arranjos de antenas para transmitir a informação. Impulsionada pelo rápido progresso nas áreas de computação e de circuitos integrados, esta tendência culminou na adoção de técnicas MIMO pela primeira vez no padrão de uma rede móvel celular em uma das versões do HSDPA( release 7) [3]. Pouco tempo depois, o desenvolvimento do LTE abriu um novo paradigma, tornando-se o primeiro sistema celular em nível global tendo MIMO como um de seus componentes chaves desde o início.

A transmissão em múltiplas antenas no LTE é feita em dois estágios: mapeamento em camadas e precodificação. No primeiro destes, os dados a serem transmitidos são mapeados em diferentes camadas. No segundo estágio uma regra de precodificação é aplicada sobre cada uma das diferentes camadas de dados [17].

Para o LTE são previstos modelos MIMO tanto para diversidade espacial como para multiplexação espacial. Cada um destes conceitos ficará mais claro no capítulo 3. Na seção 3.5 discorre-se um pouco mais sobre os modelos MIMO propostos para o LTE.

\subsubsection{Estrutura de Protocolos}

A estrutura básica da pilha de protocolos para o enlace direto do LTE está na Figura 2.4. A estrutura é dividida basicamente em três camadas: RLC (Radio Link Control - Controle do Enlace de Rádio), MAC (Medium Acess Control - Controle do Meio de Acesso) e PHY (Physical Layer Camada Física).

As camadas RLC e MAC são responsáveis entre outras tarefas por fazer o gerenciamento da transmissão e a multiplexação do fluxo de dados. Na camada física os dados a serem transmitidos são codificados (codificação turbo) e modulado segundo uma das técnicas presentes na seção 2.2.3. É também nesta última camada que os símbolos serão mapeados nas diferentes antenas no caso de transmissão MIMO.

O escalonador é o elemento que determina em cada subquadro para quais usuários serão disponibilizados recursos da rede, em quais frequências esses recursos estarão alocados e qual a taxa de transmissão a ser utilizada. No LTE, tanto para o enlace direto como para o enlace reverso, o escalonador é dependente da variação da qualidade do canal, se localizando em ambos os casos na estação base [1]. Para ajudar nesta função, a qualidade instantânea do canal nos terminais é estimada e retroalimentada à estação base a cada subquadro. A pequena duração do subquadro (1ms) 


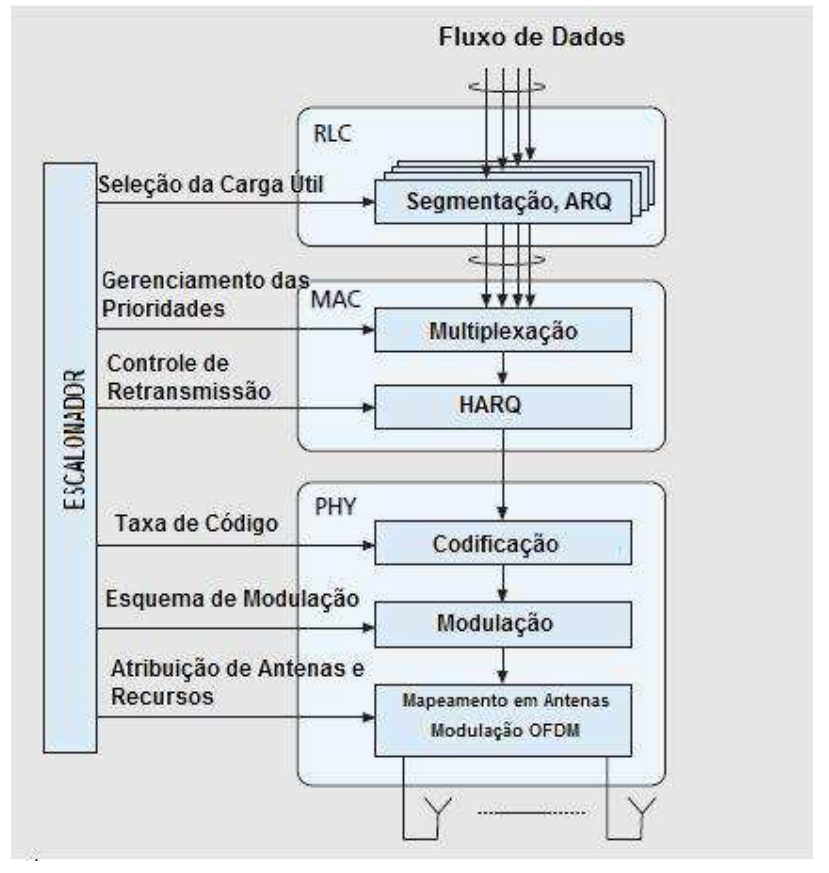

Figura 2.4: Estrutura de protocolos para o enlace direto do LTE (simplificada).

permite que o escalonador se utilize de informações mesmo de canais que variam rapidamente no tempo.

Para dar suporte a todas as ferramentas disponiveis na tecnologia, é necessário que as decisões do escalonador, realimentações do mecanismo HARQ, informações das condições do canal e outras sinalizações de controle sejam comunicadas entre a estacão base e o terminal móvel. No enlace direto, a sinalização de controle se utiliza tipicamente dos três primeiros símbolos OFDM de cada subquadro [16]. A taxa de código da sinalização de controle para cada terminal pode ser ajustada individualmente para atender às condições instantâneas do canal e minimizar o overhead [1] . 


\section{Capítulo 3}

\section{MIMO}

Este capítulo visa uma revisão nos conceitos básicos por trás de sistemas MIMO, buscando analisar as vantagens e desafios na sua implementação.

\subsection{Introdução}

Os múltiplos percursos presentes em muitas das realizações do canal físico dos sistemas de comunicação sem fio se constitui em um dos principais obstáculos na busca de elevar a capacidade total destas redes. Desde as primeiras implementações muitos estudos foram produzidos na tentativa de encontrar soluções que maximizem a taxa de transmissão atendendo a certas requisições de qualidade face a um canal altamente seletivo [23].

Aumentar a largura de banda utilizada ou elevar a potência do transmissor são duas soluções intuitivas, porém impraticáveis. No primeiro caso, porque o espectro eletromagnético é um recurso escasso e extremamente caro; no segundo, porque aumentar indefinidamente a potência do transmissor exigiria grande investimento em equipamentos (por exemplo na fabricação de amplificadores extremamente lineares), representaria um gasto proibitivo em energia por parte das operadoras e um consumo indesejável da bateria do terminal móvel, além de aumentar consideravelmente os níveis de interferência entre os usuários da rede e entre as diferentes tecnologias.

Na busca de opções economicamente viáveis para contornar estes obstáculos, outras estratégias foram propostas ao longo dos anos, como por exemplo [24]:

- diversidade;

- controle de potência do transmissor;

- adaptação do enlace;

- codificação de canal;

Algumas das técnicas supracitadas apresentam desvantagens que tornam suas implementações pouco atrativas para o caso real, outras foram utilizadas na prática, mas permanecia ainda a grande necessidade em aumentar a eficiência espectral para que essas redes fossem capaz de fornecer taxas 
ainda maiores de transmissão para uma mesma banda alocada. Este fato motivou a busca de técnicas alternativas que criassem um modelo novo nos sistemas de comunicação sem fio. Destes estudos culminou a adoção de sistemas com múltiplas antenas transmissoras e múltiplas antenas receptoras (MIMO).

Dependendo da aplicação, as múltiplas antenas dispensadas em um enlace podem servir para perceber diferentes vantagens ao sistema [2] (ver seção 3.2):

- ganho de arranjo;

- diversidade espacial;

- mutiplexação espacial.

As vantagens oferecidas no emprego de um conjunto de elementos transmissores e receptores podem ser interpretadas como o resultado da transformação de um canal entre transmissor e receptor em diversos canais individuais separados espacialmente.

A partir da exploração da dimensão espacial criada pelos vários canais que se formam entre transmissor-receptor, é possível atingir ganhos consideráveis para o enlace e é possível alcançar um aumento significativo na taxa de transmissão de dados - comparando-se com um sistema SISO Single-Input Single-Output - sem aumento adicional na largura de banda disponível ou mesmo no nível de potência do transmissor. Essa dimensão extra pode ser atingida pelo uso exclusivo de múltipas antenas no transmissor (MISO - Multiple-Input Single-Output) ou no receptor (SIMO Single-Input Multiple-Output). Sistemas com essas configurações, MISO e SIMO, são capazes de fornecer ganho de arranjo e de diversidade espacial.

\subsection{Benefícios de Sistemas MIMO}

\subsubsection{Ganho de Arranjo}

Intrinsecamente relacionado com a geometria espacial o ganho de arranjo representa um acréscimo na razão sinal ruído (SNR) no receptor obtido por meio da combinação coerente dos sinais recebidos nas diversas antenas. Pode ser obtido a partir de um pré-processamento no transmissor ou de um pós processamento no receptor.

\subsubsection{Diversidade Espacial}

Para entender como funciona a estratégia de diversidade espacial é necessário estabelecer o conceito de diversidade. Em síntese, diversidade é a técnica que busca transmitir a informação em realizações distintas do canal (ramos), com o objetivo de diminuir a probabilidade de erros no receptor.

Desde que os ramos de diversidade experimentem realizações do canal com baixa correlação entre si, é possível que um ou mais ramos sejam recebidos corretamente, ainda que alguns apresentem sinais recebidos com baixa qualidade. Esta idéia segue o conceito elementar de estatística 
de que a probabilidade de que $N$ amostras independentes de um determinado processo estejam abaixo de um determinado nível será $p_{e}^{N}$, se $p_{e}$ for a probabilidade de que um destas amostras esteja abaixo desse mesmo nível.

Existem diferentes estratégias de se explorar a diversidade como, por exemplo:

- Diversidade Temporal - Obtida por embaralhamento ou espalhamento (interleaving) da informação transmitida em conjunto com um código corretor de erros, isto é, a diversidade temporal espalha a informação codificada por diferentes instantes de transmissão de modo que as diferentes partes da palavra código sofram desvanecimentos independentes. Desta forma, com base no código corretor de erros, blocos de informação perdidos devido a um canal ruim podem ser recuperados a partir de blocos que foram recuperados precisamente. Para que esta técnica funcione, cada parte distinta da palavra código deve estar separada das demais por um tempo superior ao tempo de coerência do canal, implicando, pois, em atrasos grandes para canais que variam lentamente no tempo.

- Diversidade na frequência - De maneira análoga à técnica anterior, a diversidade na frequência busca aproveitar a seletividade frequencial de um canal para que partes distintas da informação experimentem desvanecimentos independentes. É pouco atraente em casos onde a banda de coerência do canal se aproxima da largura de banda do sinal transmitido.

- Diversidade Espacial - Utiliza múltiplas antenas receptoras e/ou transmissoras tentando combinar, selecionar ou chavear o sinal recebido. Todavia esta estratégia aumenta o custo computacional do sistema receptor, consequentemente, para o enlace direto acarreta em um consumo de potência elevado das unidades móveis.

A diversidade espacial mitiga os efeitos do canal utilizando-se para tal dos diversos subenlaces gerados entre as múltiplas antenas do transmissor e do receptor que apresentem desvanecimento suficientemente descorrelacionado. A Figura 3.1(a) ilustra essa estratégia.

O ganho de diversidade é tipicamente exresso em termos de ordem de diversidade, que pode se referir tanto ao número de ramos de diversidade efetivamente independentes ou a inclinação da curva da taxa de erro de bit (BER) em função da razão sinal-ruído. A ordem máxima de diversidade que um sistema é capaz de atingir sob certas condições do canal é $M_{T} M_{R}$ [25].

\subsubsection{Multiplexação Espacial}

O uso de múltiplas antenas no transmissor e no receptor podem ser usados em alguns casos para criar diversos canais paralelos de comunicação. A multiplexação espacial apoia-se na existência desses canais paralelos para transmitir informações distintas (em um mesmo instante de tempo e na mesma frequência) em diferentes antenas. O objetivo neste caso não é melhorar o desempenho da taxa de erro do sistema, mas sim, aumentar a eficiência espectral ao permitir o reúso dos recursos do sistema.

A multiplexação espacial pode ser basicamente de dois tipos: Multiplexação multi-usuário 3.1(b) e Multiplexação usuário-único 3.1(c). No segundo caso, os fluxos de dados transmitidos nas 
diferentes antenas são enviados a um mesmo usuário, enquanto no primeiro cada fluxo de dados tem um destinatário diferente, e o reúso dos recursos é utilizado para alocar a maior quantidade possível de usuários.

Chama-se de ganho de multiplexação o fator multiplicativo pelo qual a eficiência espectral é aumentada em comparação com um sistema SISO (Single-Input Single-Output - única-entrada única-saída). No melhor caso esse ganho é dado por $\min \left(M_{T}, M_{R}\right)[26]$.

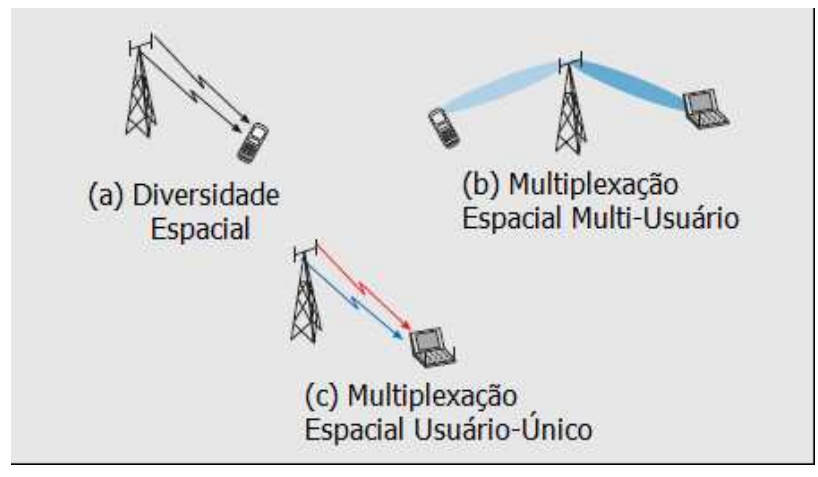

Figura 3.1: Diferentes Estratégias de Transmissão MIMO [1]

\subsection{Decomposição em paralelo do canal MIMO}

Considere o sistema MIMO representado na Figura 3.2, $\operatorname{com} \mathbf{x}=\left[\begin{array}{lllll}x_{0} & x_{1} & x_{2} & \ldots & x_{M_{T}}\end{array}\right]$ e $\mathbf{y}=$ $\left[\begin{array}{lllll}y_{0} & y_{1} & y_{2} & \ldots & y_{M_{R}}\end{array}\right]$ denotando, respectivamente, o vetor de símbolos recebidos e o vetor de símbolos transmitidos em uma dada frequência, onde $x_{i}$ representa o símbolo transmitido na i-ésima antena transmissora e $y_{j}$, o símbolo recebido na j-ésima antena receptora.

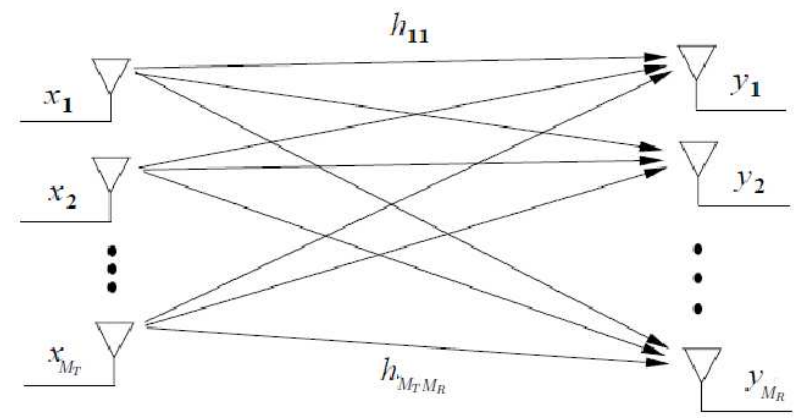

Figura 3.2: Modelo Simplificado de um Sistema MIMO [2]

Ainda neste modelo, os coeficientes $h_{j, i}$ do canal de transmissão podem ser representados conjuntamente em uma matriz $\mathbf{H}, M_{R} \times M_{T}$. A relação entre $\mathbf{y}$ e $\mathbf{x}$ é descrita, sob estas considerações, pela Equação (3.1), em que $n$ de tamanho $M_{R}$ é o vetor coluna que representa o ruído nas antenas receptoras.

$$
\mathbf{y}=\mathbf{H x}+\mathbf{n}
$$


Segundo a teoria de matrizes, para quaisquer $h_{j, i}$, a matriz $\mathbf{H}$ pode ser reescrita a partir da sua decomposição em valores singulares (SVD - Singular Value Decomposition) [3]:

$$
\mathbf{H}=\mathbf{U} \boldsymbol{\Sigma} \mathbf{V}^{H} .
$$

em que $\mathbf{U}$ e $\mathbf{V}$ são matrizes unitárias de dimensões $M_{R} \times M_{R}$ e $M_{T} \times M_{T}$, respectivamente, i.e, $\mathbf{U}^{H} \mathbf{U}=\mathbf{I}_{M_{T}}$ e $\mathbf{V}^{H} \mathbf{V}=\mathbf{I}_{M_{R}}$. E $\boldsymbol{\Sigma}$ é a matriz - $M_{R} \times M_{T}$, tal que seus elementos $\Sigma_{i, j}$ são dados por

$$
\Sigma_{i, j}=\left\{\begin{array}{l}
\beta_{i}, \text { se } \mathrm{i}=\mathrm{j} \\
0, \text { c.c. }
\end{array}\right.
$$

onde $\beta_{i}$ representa o i-ésimo valor singular de $\mathbf{H}$ convenientemente ordenado de forma decrescente.

Se transmissor e receptor têm ambos conhecimento dos coeficientes do canal é possível realizar pré e pós processamento do sinal transmitido a partir de transformações lineares que permitam fazer a decomposição em paralelo do canal. Para tal, transmite-se no lugar de $\mathbf{x}$, sua versão precodificada $\widetilde{\mathbf{x}}=\mathbf{V}^{H} \mathbf{x}$. No receptor uma operação semelhante deve ser realizada, multiplicandose o sinal recebido por $\mathbf{U}^{H} \mathbf{y}$. A figura 3.3 ilustra estas transformações.

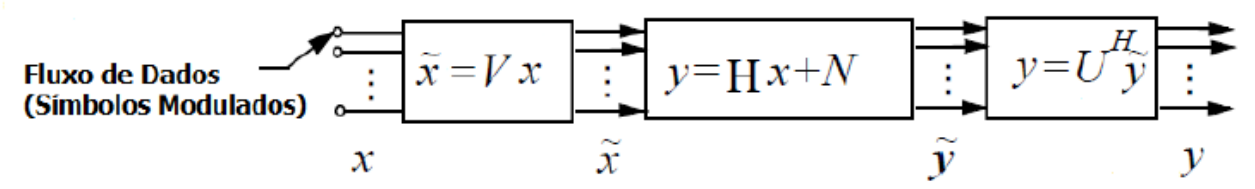

Figura 3.3: Processamento do sinal no transmissor e receptor para decomposição do canal MIMO em canais paralelos [2]

Como resultado destas transformações, ter-se-á:

$$
\widetilde{\mathbf{y}}=\mathbf{H} \widetilde{\mathbf{x}}+\mathbf{n}
$$

usando a Equação(3.2) e as transformações lineares propostas

$$
\begin{aligned}
& \mathbf{y}=\mathbf{U}^{H}(\mathbf{U} \boldsymbol{\Sigma} \mathbf{V} \widetilde{\mathbf{x}}+\mathbf{n}) \\
& =\mathbf{U}^{H}\left(\mathbf{U} \boldsymbol{\Sigma} \mathbf{V}^{H} \mathbf{V} \mathbf{x}+\mathbf{n}\right) \\
& =\mathbf{U}^{H} \mathbf{U} \boldsymbol{\Sigma} \mathbf{V}^{H} \mathbf{V} \mathbf{x}+\mathbf{U}^{H} \mathbf{n} \\
& =\mathbf{\Sigma} \mathbf{x}+\mathbf{U}^{H} \mathbf{n} .
\end{aligned}
$$

A multiplicação por uma matriz unitária não altera a distribuição do ruído. Portanto as componentes de ruído $\mathbf{U}^{H} \mathbf{n}$ e $\mathbf{n}$ são distribuídas de maneira idêntica, e a primeira não degrada a razão sinal-ruído. Ademais, como $\boldsymbol{\Sigma}$ é uma matriz cujos elementos de sua diagonal principal contém os valores singulares $\beta_{i}$ de $\mathbf{H}$, é possível notar a partir de uma observação atenta sobre a Equação (3.5) que há uma decomposição do canal MIMO em canais paralelos, e que para o i-ésimo canal formado $x_{i}$ é a entrada, $y_{i}$ denota a saída, $\beta_{i}$, o coeficiente do canal e $\widetilde{n}_{i}$ o ruído (tomando $\left.\widetilde{n}=\mathbf{U}^{H} \mathbf{n}\right)$, conforme mostra a Equação (3.6).

$$
y_{i}=\beta_{i} x_{i}+\tilde{n}_{i}
$$


Fica claro, que o número de canais paralelos gerados é definido pelo número de valores singulares $\beta_{i}$ que são diferentes de zero. Define-se então o posto ou poso de $\mathbf{H}$, denotado por $\xi$, o número de seus valores singulares diferentes de zero. Na prática o posto confere uma medida de correlação entre os coeficientes do canal. Se $\xi=1$, os canais entre cada par transmissor-receptor são altamente correlacionados e não há ganho conceitual em realizar transmissão/recepção em múltiplas antenas. A medida que essa correlação diminui o valor de $\xi$ aumenta gradativamente. Se $\mathbf{H}$ tiver rank cheio, então $\xi=\min \left\{M_{T}, M_{R}\right\}$. Idealmente se espera, pois, para melhor exploração dos recursos oferecidos pelo sistema MIMO que os canais sejam perfeitamente descorrelacionados entre si.

A Figura 3.4 ilustra a decomposição do canal MIMO em canais paralelos que possibilita ao canal MIMO suportar $\xi$ vezes a taxa de transmissão do sistema com apenas uma antena transmissora e uma antena receptora sem comprometer severamente a complexidade dos algoritmos de recepção. Com efeito, como o resultado dessa decomposição elimina a interferência co-canal a complexidade do algoritmo ótimo de demodulação ML (Maximum Likelihood - Máxima Verossimilhança) aumenta linearmente $\operatorname{com} \xi$, que representa o número de enlaces diferentes a serem decodificados.

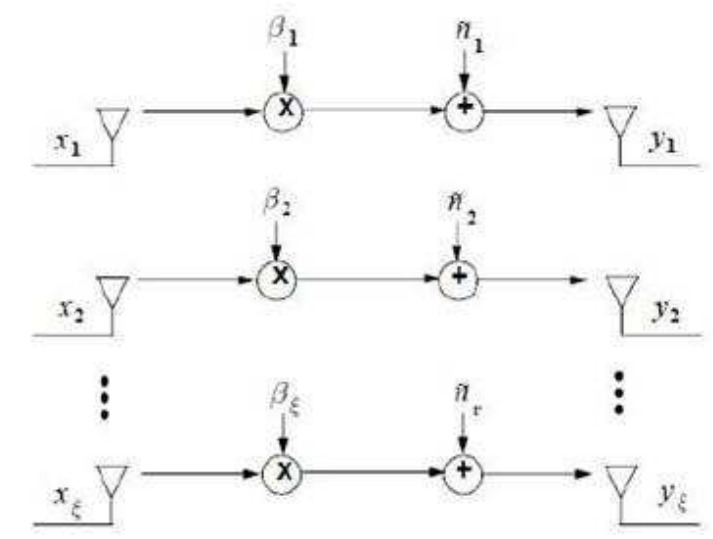

Figura 3.4: Decomposição em Paralelo do Canal MIMO [3]

Contudo, a performance associada a cada um dos canais estará associada ao seu desvanecimento $\beta_{i}$. Valores pequenos de $\beta_{i}$ diminuem a potência do ruído no receptor, enquanto valores maiores tornam o sinal mais insensível ao ruído. É possível um ajuste dinâmico de potência para as antenas do transmissor de forma a maximizar a capacidade do sistema, conferindo maior prioridade aos canais de boa qualidade [27]. Uma das formas amplamente conhecida de se realizar essa operação é pelo critério de waterfilling [28]. Segundo este critério para uma potência total transmitida restrita a um limite $\sigma$ o ajuste ótimo da potência de cada transmissor $\left(\sigma_{i}\right)$ capaz de atingir a capacidade máxima do sistema é dado por:

$$
\sigma_{i}=\left[\mu-1 /\left(\sigma \beta_{i}^{2}\right)\right]_{+}
$$

onde $[a]_{+}$é igual a $a$, se $a$ for positivo ou, caso contrário, zero e $\mu$ é um parâmetro a ser ajustado de forma tal que as restrições sobre a potência total sejam satisfeitas. Vale ressaltar que, em alguns casos, canais em que $\beta_{i}$ tiver módulo muito pequeno em relação aos demais valores singulares podem receber potência igual a zero pelo transmissor. Neste caso, estes canais são descartados 
pelo critério de waterfilling devido a sua baixa qualidade e o número total de canais paralelos gerados se torna inferior a $\xi$.

A decomposição do canal MIMO em canais paralelos permite que cada um destes canais gerados dê suporte para um fluxo independente de dados. Mostrou-se dessa forma como o sistema MIMO pode ser utilizado para se obter um ganho de multiplexação máximo $g_{d}=\xi$. Mas outras estratégias podem ser adotadas para prover diversidade espacial ao sistema. Nesta configuração, o vetor $\mathbf{x}$ apresenta graus de redundância em suas entradas.

Uma forma comumente adotada para se explorar diversidade espacial é a formação de feixe (beamforming). Neste caso o mesmo símbolo é transmitido ponderado por um fator complexo em cada uma das antenas transmissoras. Forçando que a matriz de covariância do canal tenha posto unitário. Uma estratégia de formação de feixe corresponde a simplificação da Equação (3.4), substituindo as matrizes $\mathbf{U}$ e $\mathbf{V}$ por dois vetores $\mathbf{u}$ e $\mathbf{v}$, como indicado na Figura 3.5. O símbolo $x$ transmitido é enviado na i-ésima antena ponderado por um fator $v_{i}$ e no receptor é multiplicado pelo fator $u_{i}$, normalizados de forma tal que $\|\mathbf{u}\|=\|\mathbf{v}\|=1$.

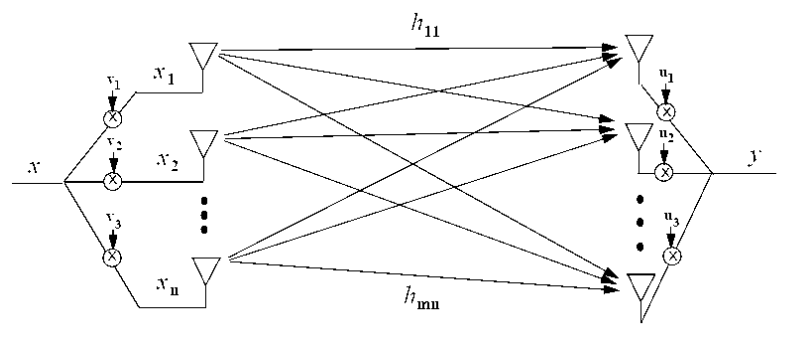

Figura 3.5: Formação de Feixe em um Canal MIMO para diversidade espacial. [3]

A formação de feixe provê ganho de diversidade a partir de uma combinação coerente dos múltiplos ramos do sinal. Nesse caso, assume-se conhecimento do canal no receptor, uma vez que este é requerido para efetuar coerentemente a combinação. Quando $\mathbf{H}$ é conhecido também no transmissor a SNR pode ser otimizada pela escolha apropriada de $\mathbf{u}$ e $\mathbf{v}$ sendo os vetores principais a direita e a esquerda da decomposição de $\mathbf{H}$.

Uma outra forma comum de se obter diversidade espacial é através das codificações em blocos como o STBC(Space Time Block Code - Codificação em Blocos no espaço e tempo) - também conhecidos como código de Alamouti [29] - projetados para atingir outras características como ortogonalidade que permitam simplificar o trabalho do receptor ou melhorar o desempenho da codificação, como por exemplo o bastante conhecido código de Alamouti.

\subsubsection{Compromisso entre diversidade e multiplexação}

Um dos aspectos fundamentais de qualquer técnica MIMO reside no fato de que para qualquer configuração multi-antena o sistema não é capaz de extrair concomitantemente os ganhos máximos de diversidade e multiplexação. Pode-se afirmar que existe um comprometimento entre usar a dimensão espacial gerada pelas múltiplas antenas do sistema para mitigar os efeitos de desvanecimento do canal (diversidade) ou utilizá-los para cancelar a interferência entre múltiplos fluxos que reusam os recursos do canal em subenlaces distintos (multiplexação). Consequentemente existe 
um compromisso entre o número de fluxos de dados multiplexados através do canal MIMO e o grau de diversidade que cada um deles pode apreciar.

Este compromisso pode ser formulado do ponto de vista da teoria da informação [24]. Se chamarmos de $g_{d}$ a ordem de diversidade e de $g_{r}$ o ganho de multiplexação, vale a relação presente na Equação (3.8).

$$
g_{d}\left(g_{r}\right)=\left(M_{T}-g_{r}\right)\left(M_{R}-g_{r}\right)
$$

A Figura 3.6 ilustra a curva de compromisso entre a ordem de diversidade e o grau de multiplexação que um sistema pode atingir, no melhor caso (os canais MIMO são descorrelacionados).

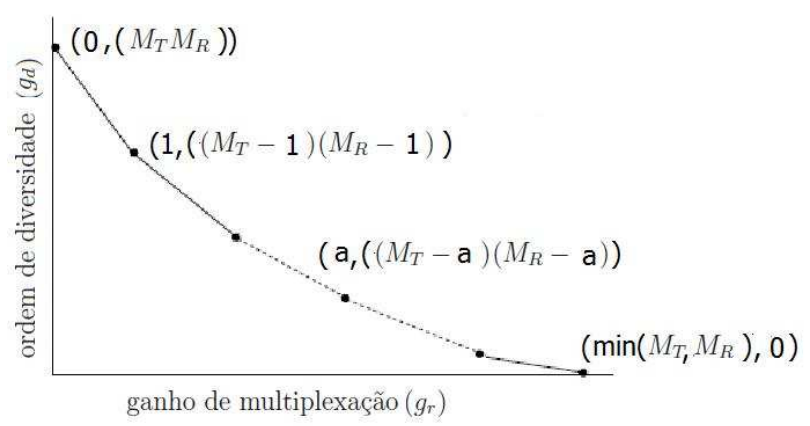

Figura 3.6: Gráfico de compromisso entre os graus de diversidade e multiplexação espacial

\subsection{Limitações dos Sistemas MIMO}

\subsubsection{Visão Geral}

A decomposição em paralelo do canal MIMO, feita na equação 3.5, é um dos passos no caminho da solução ótima - em termos de capacidade - para esse tipo de sistema. Contudo, a obtenção das matrizes U e V está intrinsecamente relacionada com o CSI (Channel State InformationInformação do Estado do Canal), tanto no receptor como no transmissor. Embora na prática o receptor realize uma estimação do canal físico - inerente ao processo de recepção - por meio de um número finito de símbolos pilotos inseridos no quadro transmitido, para que essa informação esteja disponível ao transmissor é necessário que haja um caminho de realimentação.

Em sistemas FDD, com o enlace direto e reverso bem separados na frequência, é necessário um canal de feedback (realimentação) alocado em uma banda separada para levar a estimação do transmissor para o receptor. O inconveniente de se ter diversos enlaces em malha fechada é a ocupação de parte da banda disponível para acomodação dos canais de feedback.

Para o caso TDD, o próprio transmissor pode efetuar a estimação do canal físico por meio de sinalização realizada entre receptor e transmissor em determinados instantes de tempo. No LTE os subquadros especiais de sinalização (ver Seção 2.2.2) preveem suporte para esse tipo de controle.

Observa-se, portanto, que o conhecimento dos coeficientes do canal para transmissor e receptor serão versões estimadas dos valores reais. Assim, o desempenho da decomposição proposta na 
equação 3.3 está inexoravelmente ligado à qualidade da estimação realizada. Em ambientes nos quais a resposta do canal varie lentamente é possível proceder uma estimação confiável sem comprometer o sistema. Mas em algumas situações a estimação de um desvanecimento rapidamente variante no tempo pode ser deveras custosa ao sistema, exigindo um número grande de pilotos e uma atualização constante da informação (forçando o recálculo da estimação em intervalos muito curtos de tempo), com as dimensões adicionais geradas por uma configuração MIMO agravando ainda mais a complexidade dos cáculos realizados. Em determinadas realizações o intervalo de atualização da estimação pelo receptor é inferior ao tempo de coerência do canal e o reúso da informação pode degradar a perfomance do sistema.

Outro obstáculo a ser enfrentado é a latência da rede. Em termos práticos é impossível que o CSI seja utilizado para realizar instantaneamente o pré-processamento do sinal. Existe um tempo decorrido desde o envio da resposta do receptor ao transmissor até o instante em que de fato essa informação gera efeitos na precodificação do transmissor. No LTE a latência no plano do usuário está prevista para ser inferior a 5 subquadros. Como agravante a este fato, deve-se ressaltar que a estimação - em geral feita com a ajuda de símbolos pilotos - refere-se ao instante passado do canal (aquele no qual os pilotos foram transmitidos) portanto, pela sua própria natureza, o conhecimento do CSI representa sempre uma versão defasada do canal real.

Além desses fatores, fica claro pela Equação (3.5), a relação entre os benefícios de um canal MIMO e o posto da matriz $\boldsymbol{\Sigma}$, que indica o número de enlaces independentes efetivamente gerados. Na situação ideal, a matriz $\mathbf{H}$ deve ter posto cheio, i.e., as antenas devem estar idealmente descorrelacionadas. Sob esta ótica, o projeto das antenas e o ambiente de propagação assumem um papel preponderante para se extrair ganhos de um sistema MIMO.

A proximidade entre as antenas no equipamento dos usuários pode implicar grande correlação, especialmente em casos onde há linha de visada na propagação do sinal ou o ambiente é pouco dispersivo. Como consequência o caso multi-usuário apresenta certa vantagem se comparado ao caso usuário-único por ser mais robusto ao nível de espalhamento do sinal, uma vez que na maioria das vezes os múltiplos usuários estão distantes uns dos outros. Entretanto, existe uma contrapartida: no enlace direto a capacidade da estação-base de realizar a conformação de feixe adequada depende do conhecimento do CSI. Assim, no caso extremo de indisponibilidade do CSI na estação-base no enlace direto e estatísticas de desvanecimento idênticas para todos os usuários, os ganhos do caso multi-usuário desaparecem e a estratégia usuário-único passa a ser ótima.

\subsubsection{Resultados Comparativos}

\subsubsection{Cenário de Simulação}

Para avaliar o impacto da latência e do erro de estimação sobre o sistema, contemplou-se estes cenários a luz do $\mathrm{WiSiL}^{1}$ - um simulador de enlace para o LTE desenvolvido dentro de um projeto de mesmo nome em parceria entre o LEMOM/ENE e o INdT ${ }^{2}$. O simulador foi desenvolvido para atender às especificações da camada física para o enlace direto desta tecnologia.

\footnotetext{
${ }^{1}$ Wireless Simulator Laboratory

${ }^{2}$ Instituto Nokia de Tecnologia
} 
Tabela 3.1: Cenário de Simulação para o canal MIMO decomposto em canais paralelos

\begin{tabular}{|c|c|}
\hline Frequência Central & $2 \mathrm{GHz}$ \\
\hline Largura de Banda & $10 \mathrm{MHz}$ \\
\hline Espaçamento entre Subportadoras & $15 \mathrm{KHz}$ \\
\hline$N_{c}$ & 600 \\
\hline$M_{T}$ & 2 \\
\hline$M_{R}$ & 2 \\
\hline Modulação & QPSK \\
\hline Codificação de Canal & Nenhuma \\
\hline HARQ / ARQ & Desabilitado \\
\hline Modo de Duplexação & FDD \\
\hline Modelo de Canal & Modelo Espacial do 3GPP \\
\hline Velocidade do Móvel & $3 \mathrm{Km} / \mathrm{h}$ \\
\hline
\end{tabular}

O WiSiL segue o método estatístico de Monte Carlo em suas simulações e retorna como saída, ao fim do processo, medidas de desempenho do sistema em função da razão $E_{b} / N_{0}$ : como BER e eficiência espectral, entre outros. A Figura 3.7 mostra o esquemático do fluxograma de simulação.

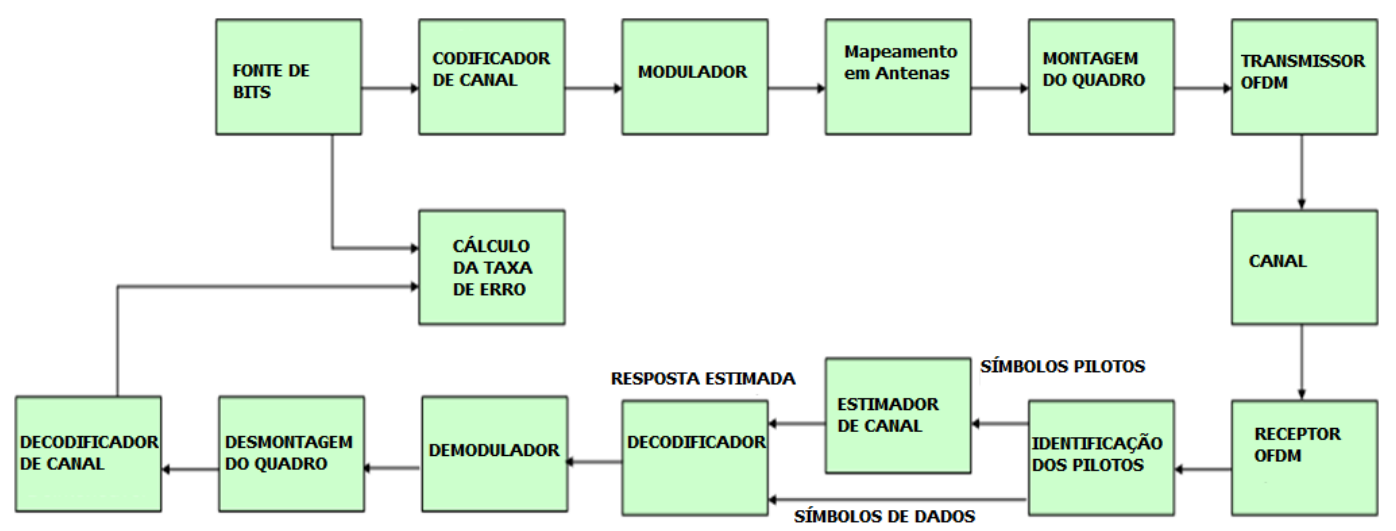

Figura 3.7: Fluxograma de Simulação do WiSiL

Com o fim de realizar a análise a que se propõe a presente seção foi implementada no simulador a decomposição em paralelo do canal, conforme feito na seção 3.3. Detalhes do cenário escolhido para a obteção dos resultados estão explicitados na Tabela 3.1.

\subsubsection{Efeito da Qualidade da Estimação}

A perfeita diagonalização da matriz $\mathbf{H}$ só é possível de se obter a partir da obtenção de $\mathbf{U}$ e V ideais. Contudo, ter essa informação precisa é muito difícil, primeiro pelo número finito de pilotos usados na estimação. Além disso, a presença do ruído no sistema receptor, prejudica essa estimação. 


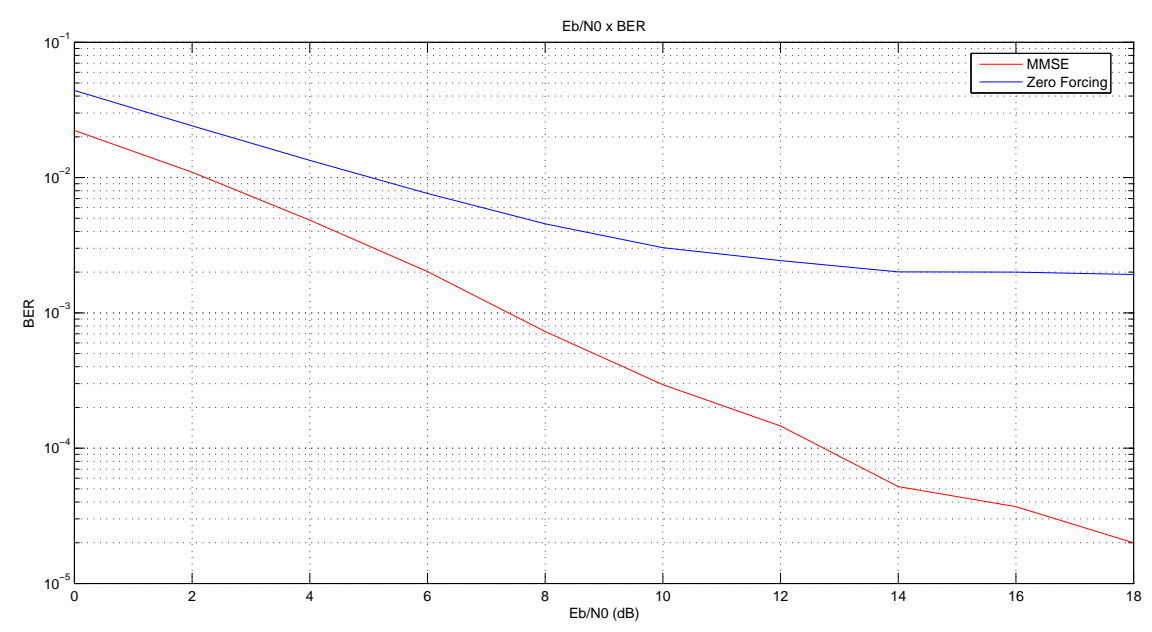

Figura 3.8: Comparação entre estimadores para diagonalização do canal MIMO

A figura 3.8 compara o desempenho do sistema em um cenário macro urbano ${ }^{3}$. para dois receptores diferentes, um do tipo MMSE (Minimum Mean Squared Error - Erro Quadrático Médio Minimo), mais robusto, e um Zero-Forcing, menos preciso. Nesta figura fica evidente como o desempenho da estimação do canal interfere na taxa de erro do sistema. Isso porque quão mais distante do ideal estiverem os valores estimados para $\mathbf{U}$ e $\mathbf{V}$, a diagonalização do sistema estará mais comprometida. Em outras palavras, haverá grande interferência entre os enlaces paralelos e a medida que essa interferência cresce mais erros serão apresentados pelo sistema.

Variando o valor da velocidade do terminal móvel da Tabela 3.1, obteve-se, como se mostra na Figura 3.9, a variação do desempenho do código em função da velocidade do móvel - em um ambiente macro urbano - para um receptor do tipo MMSE e é possível inferir que a medida que essa aumenta a uma degradação crescente na taxa de erro de bit, pois a estimação do canal piora devido a sua maior seletividade e, com isso, exige que uma maior densidade de pilotos seja enviada para tornar a recepção mais confiável.

\subsubsection{Efeito do Atraso da Informação}

Outro problema, como se viu, é o atraso da informação estimada do canal. No caso do LTE ambiciona-se uma latência média inferior a 5 ms no plano do usuário. Por esse motivo, foi considerada uma latência de 2 subquadros, i.e., de 2 ms para o atraso da estimação no precodificador. O resultado, utilizando um receptor MMSE está na Figura 3.10.

Nota-se que o processo de diagonalização do sistema falhou devido ao atraso do estimador. Isto é, em um perfil macro urbano, a velocidade de variação do canal é rápida o suficiente para que o tempo de coerência do sistema seja menor do que a latência esperada da rede.

\footnotetext{
${ }^{3}$ Os coeficientes do canal foram obtidos pelo modelo espacial do 3GPP [30] -Spatial Channel Model Extended -gerados a partir de um conjunto de rotinas em MATLAB desenvolvidos pelo projeto Winner [31]
} 


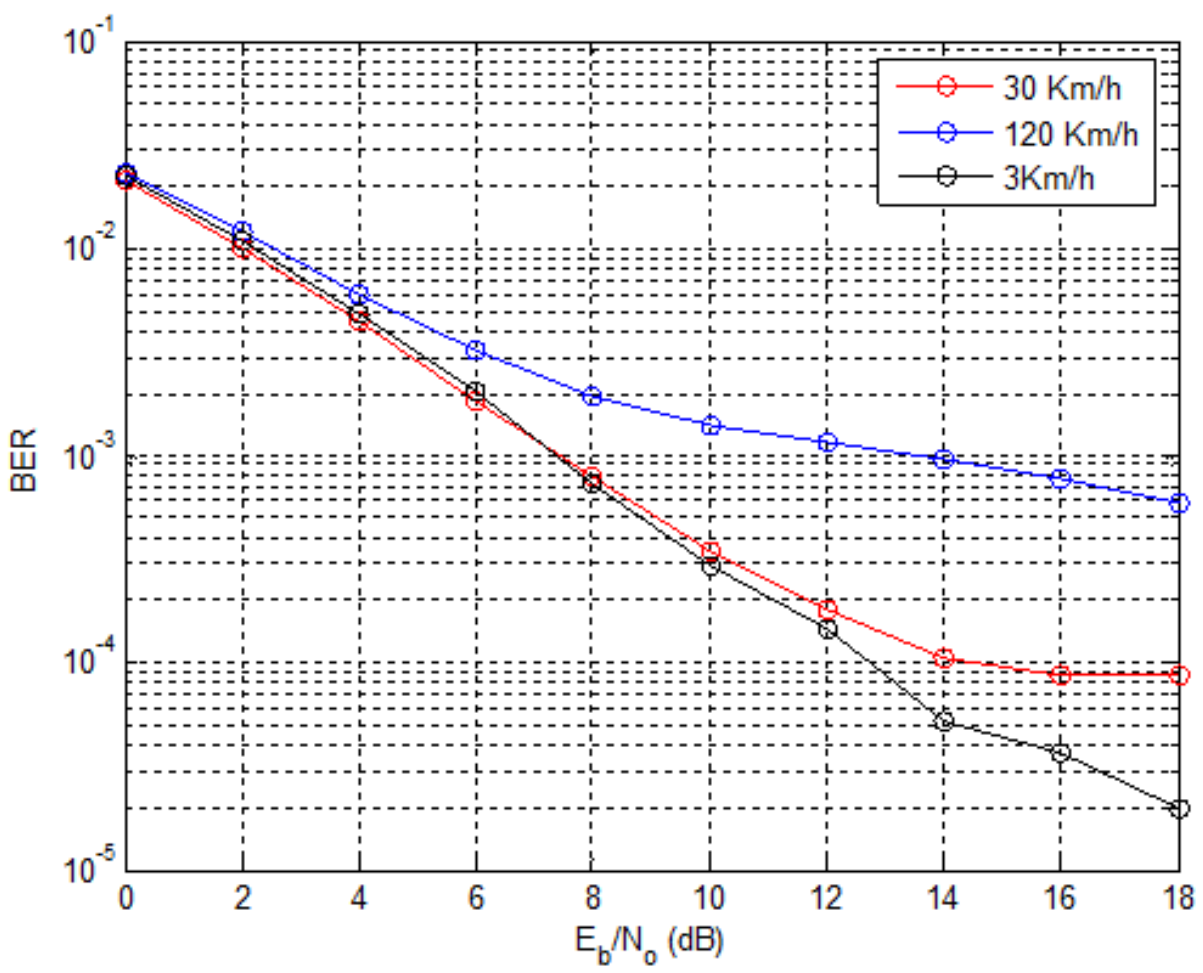

Figura 3.9: Efeito dda velocidade do móvel na diagonalização do Sistema MIMO

\subsection{MIMO no LTE}

\subsubsection{Diversidade Espacial}

As especificações do enlace direto do LTE preveem suporte para transmissões em diversidade espacial somente em duas ou quatro antenas. Os códigos usados no LTE são baesados no SFBC (Space Frequency Block Code - Codificação em Blocos no Espaço Frequência), uma versão análoga ao STBC implementada no domínio da frequência. Como existem códigos SFBCs conhecidos apenas para 2 antenas transmissoraas, para transmitir em 4 antenas o LTE usa uma combinação entre o SFBC e o FSTD (Frequency Switched Transmit DiversityDiversidade de Transmissão por Chaveamento na Frequência) [12].

Para a transmissão em SFBC o LTE mapeia a sequência $x_{k}$ de símbolos a serem transmitidos de acordo com:

$$
\left[\begin{array}{ll}
y^{(1)}(1) & y^{(1)}(2) \\
y^{(2)}(1) & y^{(2)}(2)
\end{array}\right]=\left[\begin{array}{cc}
x 1 & x 2 \\
-x 2^{*} & x 1^{*}
\end{array}\right]
$$

Onde $y^{(p)}(k)$ é o símbolo transmitido na k-ésima subportadora pela p-ésima antena. Códigos como o da Equação (3.9) partem da assunção que o canal não varia - ou varia muito pouco - entre duas subportadoras consecutivas. Embora estejam limitados a cenários com essa configuração, esses códigos apresentam a vantagem de não exigirem qualquer precodificação no transmissor e terem desempenho ótimo com um receptor linear.

Quando a transmissão é feita em 4 antenas, a combinação entre o SFBC e o FSTD resulta em 


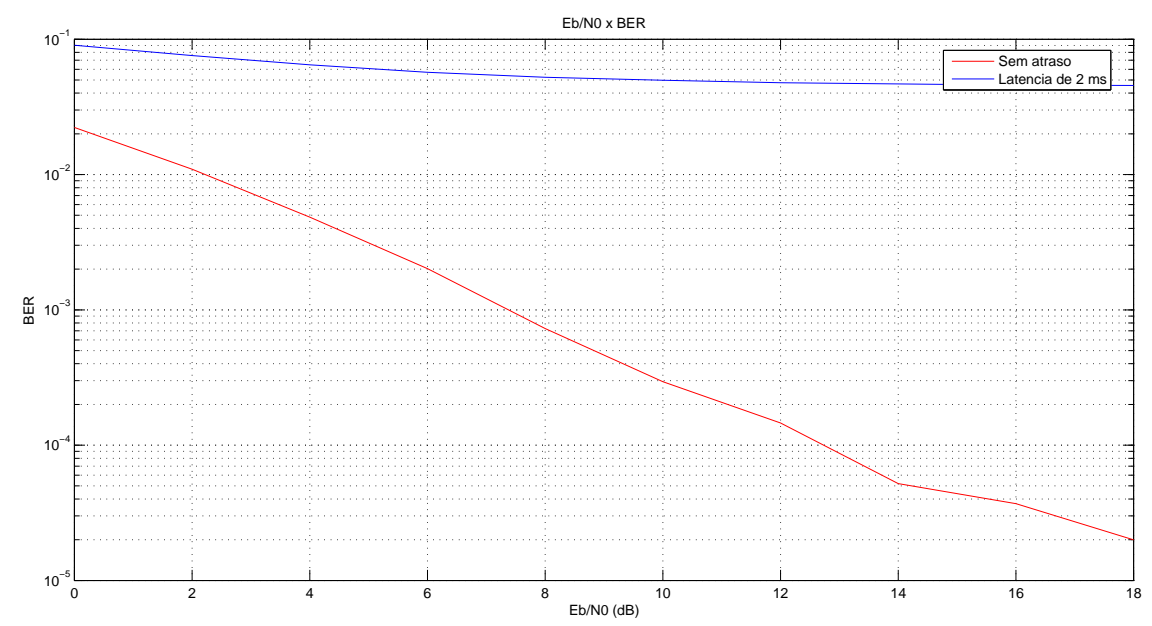

Figura 3.10: Efeito do atraso na estimação do canal para a diagonalização do Sistema MIMO

uma variação da equação 3.9 :

$$
\left[\begin{array}{cccc}
y^{(1)}(1) & y^{(1)}(2) & y^{(1)}(3) & y^{(1)}(4) \\
y^{(2)}(1) & y^{(2)}(2) & y^{(2)}(3) & y^{(2)}(4) \\
y^{(3)}(1) & y^{(3)}(2) & y^{(3)}(3) & y^{(3)}(4) \\
y^{(4)}(1) & y^{(4)}(2) & y^{(4)}(3) & y^{(4)}(4)
\end{array}\right]=\left[\begin{array}{cccc}
x 1 & x 2 & 0 & 0 \\
0 * & 0 * & x 3 & x 4 \\
-x 2^{*} & x 1^{*} & 0 & 0 \\
0 & 0 & -x 3^{*} & x 4^{*}
\end{array}\right]
$$

A diferença no mapeamento dos símbolos do SFBC na Equação (3.10) deve-se a menor densidade de pilotos nos sinais enviados pelos sinais das antenas 2 e 3 (metade das duas primeiras). Dessa forma tem-se um ganho suave, impedindo-se que as versões menos acuradas do canal estejam em apenas um dos dois SFBC chaveados.

\subsubsection{Multiplexação Espacial}

A multiplexação espacial no LTE acontecerá sempre no enlace direto, podendo ser do tipo multi-usuário ou usuário-único, com um máximo de quatro antenas na transmissão.

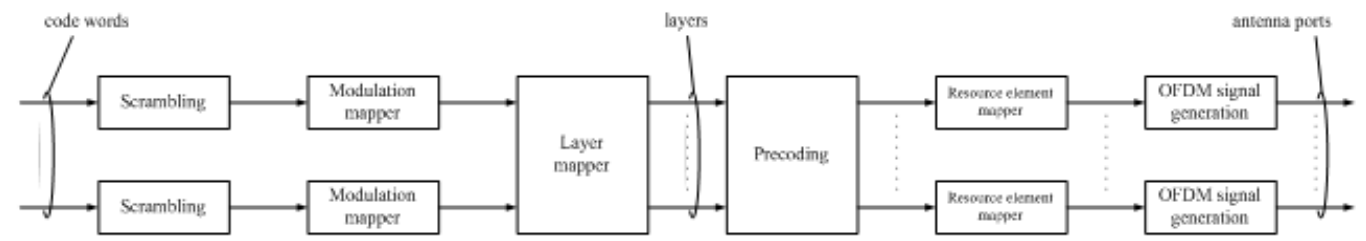

Figura 3.11: Fluxo da informação para transmissão em múltiplas antenas no LTE. [16]

O fluxograma da informação para transmissão em múliplas antenas previsto para o LTE está exposto na Figura 3.11. Para que se possa explicar os conceitos básicos por trás da especificações de multiplexação do LTE, é necessário conhecer um pouco a terminologia adotada pelo 3GPP para a padronização: 
- Camada - É o termo que designa diferentes fluxos de dados para a multiplexação espacial. Pode ser interpretado como uma regra de mapeamento dos símbolos nas antenas transmissoras. Cada camada é identificada por um precodificador diferente e pode ser associada com um padrão de radiação;

- Posto - Número de camadas transmitidas;

- Palavra-Código - Como se chama um bloco de dados independente, correspondendo por um um bloco entregue pela camada MAC para a camada física. Cada palavra código está protegida por uma chave de um código detector de erros.

Quando o posto é maior do que 1, podem ser usadas até duas palavras-código na transmissão. Contudo o número de palavras-código não pode exceder o número de camadas que por sua vez deve ser menor que o número de antenas usadas na transmissão. Se o posto for igual a 1 apenas o caso usuário-único pode ser contemplado.

A vantagem de se utilizar duas palavras-códigos na transmissão para um usuário-único é a possibilidade de realizar um algoritmo de recepção SIC (Sucessive Interference Cancelation - Cancelamento de Interferência Sucessivo) que combinado a um receptor MMSE pode levar, para efeitos teóricos, a taxas próximos do limite de Shannon [24].

A precodificação no LTE pode ser feita de duas formas: em laço aberto ou em laço fechado. No laço fechado a estação base recebe informações do usuário sobre qual deve a matriz de precodificação a ser escolhida dentro de possibilidades existentes em um livro-código predeterminado. A matriz escolhida será aquela que maximiza a capacidade do sistema baseada nas potencialidades do receptor. No laço aberto o usuário não envia informações sobre a matriz desejada, mas apenas sobre o posto do sistema. Neste último caso a precodificação se apóia em um código cíclico [32].

O livro-código que contém as matrizes de precodificação tem algumas propriedades bem definidas [3]:

- Módulo Constante - Os precodificadores aplicam apenas ajuste de fase nos sinais transmitidos. Não há alteração no módulo dos sinais, ajudando a garantir bom funcionamento dos amplificadores.

- Aninhamento - O método de arranjo do livro código garante que os livros códigos de posto mais baixo sejam subconjuntos dos livros códigos de posto mais elevado, facilitando o trabalho do receptor.

- Multiplicações de baixa complexidade- Em geral as multiplicações envolvidas no estágio de precodificação utilizam apenas fatores $\pm 1 \mathrm{e} \pm j$, diminuindo a complexidade da operação.

Para obter o ganho máximo possível de capacidade do sistema quando se usa a técnica multiusuário é necessário que o escalonador gerencie da maneira mais eficiente possível a distribuição entre recursos aos usuários. O gerenciamento dos recursos se dará em dois passos. O primeiro é a informação da qualidade do enlace informado pelo usuário a estação base. Baseado neste 
conhecimento o sistema então decidirá a forma como será feita o escalonamento entre usuários e adaptará a taxa de transmissão com que cada um receberá os dados da rede.

Não há especificações claras do LTE em relação a forma como será feito esse escalonamento. Alguns algoritmos de seleção de usuários são estudados em [33, 34, 35].

\subsubsection{Resultados Comparativos}

\subsubsection{Efeitos da Qualidade da Estimação}

Para entender a correlação entre a qualidade da estimação do canal simulou-se a técnica de diversidade proposta para o LTE, para $M_{T}=2$ e $M_{R}=2$, em um cenário macro urbano. Todos os demais parâmetros de simulação foram mantidos de acordo com o exposto na tabela 3.1.

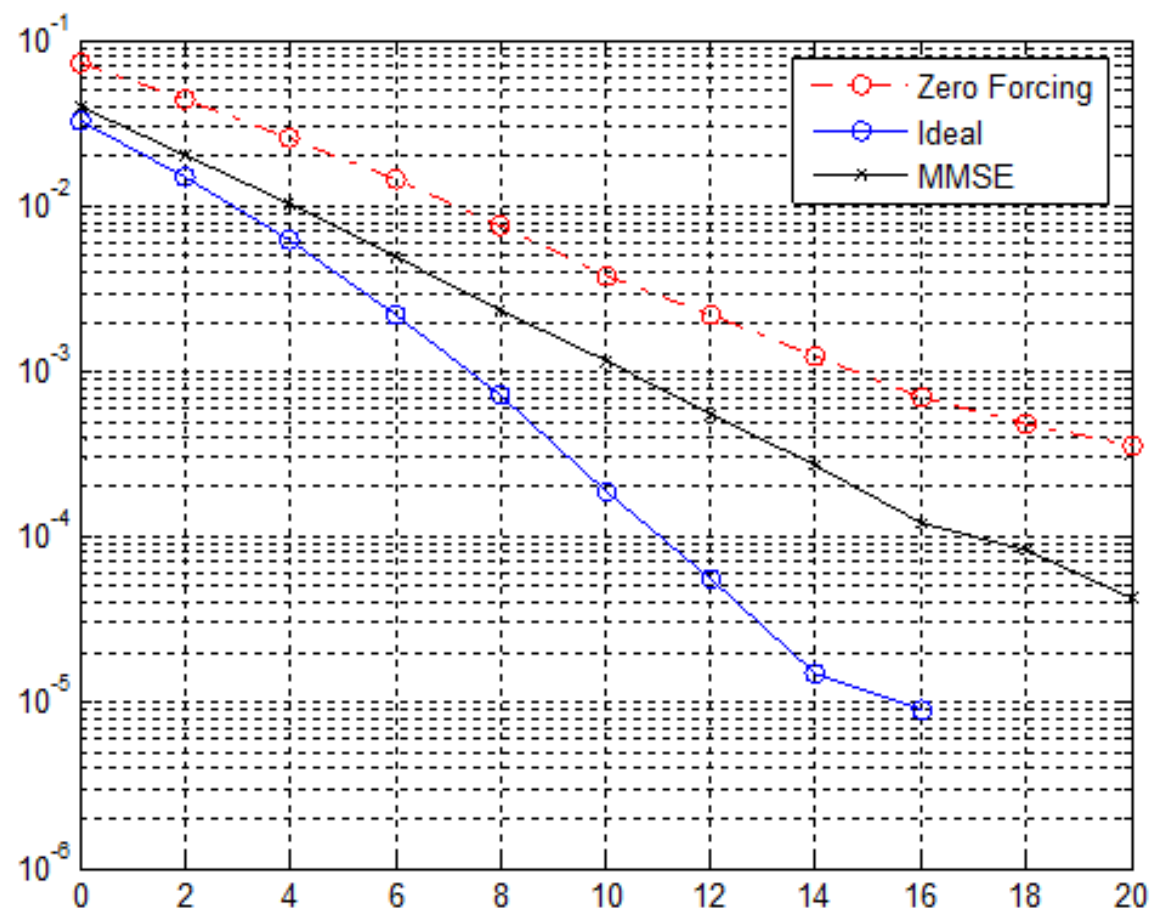

Figura 3.12: Efeito da qualidade da estimação para o SFBC.

Na primeira simulação comparou-se o desempenho de um receptor MMSE e um receptor do tipo zero-forcing com um receptor ideal, isto é, um receptor que conhece exatamente a resposta do canal. O resultado dessa simulação encontra-se na Figura 3.12. É possível notar que a medida que a robustez da estimação do canal piora, a taxa de erro de bit do sistema também é degradada. O receptor ideal tem o melhor desempenho, contudo é impraticável no caso real. Na comparação entre os receptores do tipo MMSE e zero-forcing nota-se que o MMSE tem desempenho superior, por fornecer melhor qualidade de estimação, contudo sua implementação acarreta em maior complexidade computacional.

Uma segunda simulação, na qual se variou a velocidade do terminal móvel (entre 3 e 120 


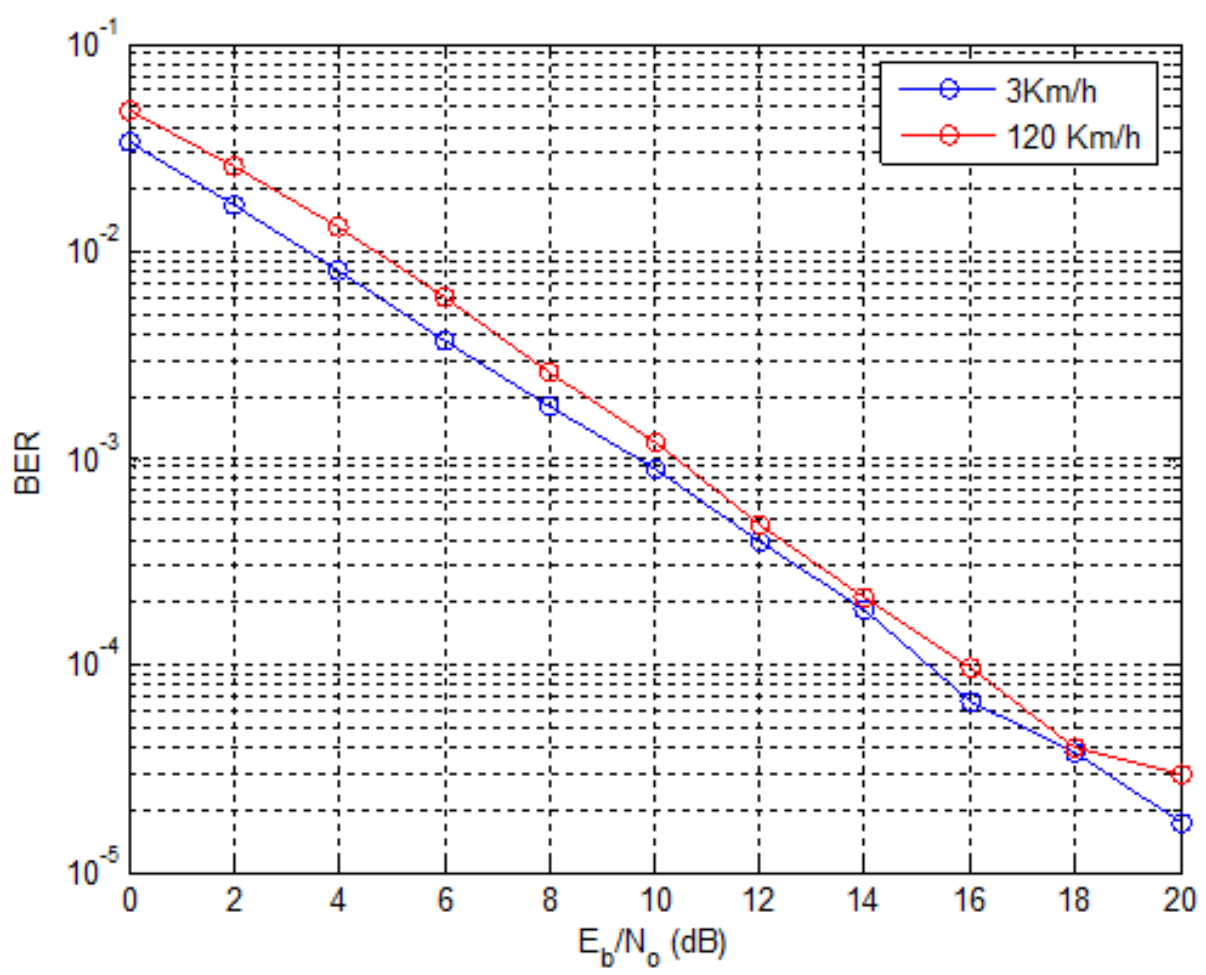

Figura 3.13: Efeito da velocidade do móvel para o SFBC.

$\mathrm{Km} / \mathrm{h}$ ) buscou verificar a relação entre um canal que varia rapidamente no tempo e o desempenho do sistema. Como os sistemas da quarta geração se propõe a alcançar taxas elevadas em alta mobilidade é necessário entender como as técnicas propostas atualmente para o LTE se comportam nessa situação.

O resultado desta segunda simulação, presente na figura 3.13, mostra que até a velocidade de $120 \mathrm{Km} / \mathrm{h}$, o desempenho do sistema não foi tão afetada pela velocidade do terminal móvel. A densidade de pilotos prevista para o LTE mostra-se razoável para esse tipo de transmissão, uma vez que mesmo a $120 \mathrm{Km} / \mathrm{h}$ o sistema é capaz de fazer a combinação dos símbolos recebidos e extrair a informação com grau de qualidade parecido com os ambientes de baixa mobilidade.

\subsection{Conclusão}

Ao longo deste capítulo, foram propostas diferentes estratégias de se utilizar configurações MIMO para se extrair ganhos de multiplexação e diversidade.

Com o objetivo de analisar o impacto da qualidade das informações do canal no receptor em um sistema que usa técnicas coerentes de diversidade espacial foram realizadas simulações onde se variou a qualidade do sistema receptor, aplicou-se atraso no conhecimento do canal no transmissor e mudou-se a velocidade do móvel (para criar canais com diferentes variabilidades).

Em todos os casos analisados, percebeu-se uma degradação da performance de ambas técnicas estudadas (divisão em paralelo do canal MIMO e SBFC) conforme variou-se a precisão do canal 
estimado.

A técnica adotada pelo LTE, o SBFC, mostrou um desempenho bom quando aplicado a ambientes de alta velocidade, o que a qualifica, em parte, a adoção do SBFC como uma alternativa para os sistemas $4 \mathrm{G}$ que buscam atingir taxas elevadas para essa condição de transmissão. 


\title{
Capítulo 4
}

\section{Códigos Não Coerentes}

\author{
Os códigos apresentam suas próprias peculiari- \\ dades e restrições. O objetivo deste capítulo é elu- \\ cidar algumas das características desses códigos, \\ com exemplos de códigos que podem ser aplicados \\ a sistemas que utilizam o OFDM como o LTE.
}

\subsection{Introdução}

No Capítulo 3, viu-se formas de alocação dos símbolos nas antenas em um sistema MIMO para extrair ganhos de multiplexação e/ou diversidade. Os esquemas apresentados se alicerçam na necessidade do conhecimento ou estimação do comportamento do canal pelo receptor, sendo chamados de códigos coerentes. O desempenho destes sistemas está intimamente relacionado, como se viu, com a precisão da estimação.

Proceder na estimação do canal, especialmente em ambientes com desvanecimento rápido seletivo em frequência, pode ser computacionalmente custoso para o sistema, mais ainda quando se opera em múltiplas antenas. Outro ônus inerente à estimação é a necessidade, entre outras coisas, do envio de símbolos de referência eviados de tempos em tempos dentro do quadro transmitido. Estes pilotos usam recursos que poderiam carregar informação líquida, mas são perdidos em função da estimação do canal.

No lado do terminal móvel o custo computacional elevado representa um grande problema, pois tanto o atraso gerado pelo tempo gasto com cálculos necessários a estimaçao podem ser prejudiciais na recuperação da informação, como a miniaturização do equipamento e o consumo de bateria podem ser comprometidos. Além disso, nem sempre os parâmetros do canal necessários para a correta estimação podem ser aferidos, mesmo no lado do receptor [10].

Estes fatos têm motivado estudos de técnicas de transmissão em que a informação seja recebida sem efetuar a estimação do canal. Técnicas que apresentam essa característica são chamadas de não coerentes e apresentam um compromisso entre perdas na taxa de erro de bit (BER), devido a completa ausência de informação sobre o estado do canal e a diminuição da complexidade do receptor.

Existem códigos que executam tanto a função do precodificador quanto a do modulador digital, 
mapeando diretamente os bits em símbolos a serem transmitidos nas antenas. Ao longo deste capítulo, serão estudados três tipos desses códigos para sistemas OFDM: código não coerente puro, código diferencial e um esquema híbrido.

\subsection{Código Não Coerente Puro}

O modelo não coerente puro (chamado de NCP doravante para simplificação da notação) proposto em [36] é de mais fácil entendimento após algumas alterações na forma de se modelar o sistema. O ponto de partida será a relação entre os símbolos transmitidos e recebidos em um sistema MIMO, para uma dada subportadora OFDM, é mostrada na equação 3.1 e repetida aqui para conveniência do leitor:

$$
\mathbf{y}=\mathbf{H x}+\mathbf{n}
$$

em que $\mathbf{H}=\mathbf{H}\left(e^{j 2 \pi \frac{k}{N_{c}}}\right)$ representa a matriz de canal para o k-ésimo tom OFDM.

Partindo-se do princípio que o enlace é feito em um canal que apresenta L multipercursos resolvíveis, uma forma de se reescrever $\mathbf{H}$ é por meio do cômputo da sua função de transferência:

$$
\mathbf{H}\left(e^{j 2 \pi \frac{k}{N_{c}}}\right)=\sum_{l=0}^{L} \mathbf{H}_{l} e^{-j 2 \pi \psi_{l} \frac{k}{N_{c}}}
$$

em que $\mathbf{H}_{l}$ é a matriz de dimensões $M_{R} \times M_{T}$ (usando a notação do capítulo 3) que representa os coeficientes do canal para o l-ésimo multipercurso, cuja chegada ocorre no instante de amostragem $\psi_{l}$. Denotando o símbolo transmitido na m-ésima antena para a k-ésima subportadora de $x_{k, m}$, então podemos escrever

$$
\mathbf{x}_{k}=\left[\begin{array}{lll}
\mathbf{x}_{k, 0} & \mathbf{x}_{k, 1} \mathbf{x}_{k, 2} & \cdots \mathbf{x}_{k, M_{T}}
\end{array}\right]^{T}
$$

como o vetor de símbolos transmitidos no k-ésimo tom OFDM. E, como consequência, receber-se-á o sinal $\mathbf{y}_{k}$ dada por:

$$
\mathbf{y}_{k}=\mathbf{H}\left(\left(e^{j 2 \pi \frac{k}{N_{c}}}\right)\right) \cdot \mathbf{x}_{k}+\mathbf{w}_{k}
$$

com $\mathbf{w}_{k}$ representando o vetor de ruído, cujas entradas são i.i.d distribuídas segundo uma variável gaussiana de média zero. Extrapolando para o símbolo OFDM inteiro, a matriz de símbolos recebidos $\mathbf{Y}$ será:

$$
\mathbf{Y}=\mathbf{Q}+\mathbf{W}
$$

em que $\mathbf{Q}=\left[\begin{array}{lllll}\mathbf{q}_{0} & \mathbf{q}_{1} & \mathbf{q}_{2} & \ldots & \mathbf{q}_{k}\end{array}\right]^{T}$ para $\mathbf{q}_{k}=\mathbf{H}\left(\left(e^{j 2 \pi \frac{k}{N_{c}}}\right)\right) \mathbf{x}_{k}$ e $\mathbf{W}=\left[\begin{array}{lllll}\mathbf{w}_{0} & \mathbf{w}_{1} & \mathbf{w}_{2} & \ldots & \mathbf{w}_{k}\end{array}\right]^{T}$.

Após algumas manipulações matriciais é possível reescrever a Equação (4.5) sem perda de generalidade, como

$$
\mathbf{Q}=\sum_{l=0}^{L} \mathbf{D}^{l} \mathbf{H}_{l} X=\mathbf{S}(\mathbf{X}) \overline{\mathbf{H}} .
$$

Neste caso, $\mathbf{S}(\mathbf{X})$, de dimensões $N_{C} \times M_{T} L$, será definida por $\mathbf{S}=\left[\begin{array}{ll}\mathbf{X} & \mathbf{D}^{\psi_{1}} \mathbf{X} \ldots \mathbf{D}^{\psi_{L-1}} \mathbf{X}\end{array}\right]$, em que $\mathbf{D}=\operatorname{diag}_{k=0}^{N_{c}-1}\left\{e^{-2 j \pi k / N_{c}}\right\}$. Ainda na equação 4.6 a matriz $\overline{\mathbf{H}}=\left[\begin{array}{llll}\mathbf{H}_{0}^{H} & \mathbf{H}_{1}^{H} & \ldots & \mathbf{H}_{L-1}^{H}\end{array}\right]^{H}$ é um arranjo matemático para facilitar o tratamento analítico do modelo construído a partir das 
matrizes $\mathbf{H}_{l}$. A matriz $\mathbf{D}^{\psi_{l}}$ corresponde a rotação de fase aplicada aos coeficientes de $\mathbf{H}_{l}$ durante o processo de convolução no tempo. A Figura 4.1 ilustra a representação na frequencia do l-ésimo mulltipercurso e ajuda a entender o surgimento da matriz $\mathbf{D}$.

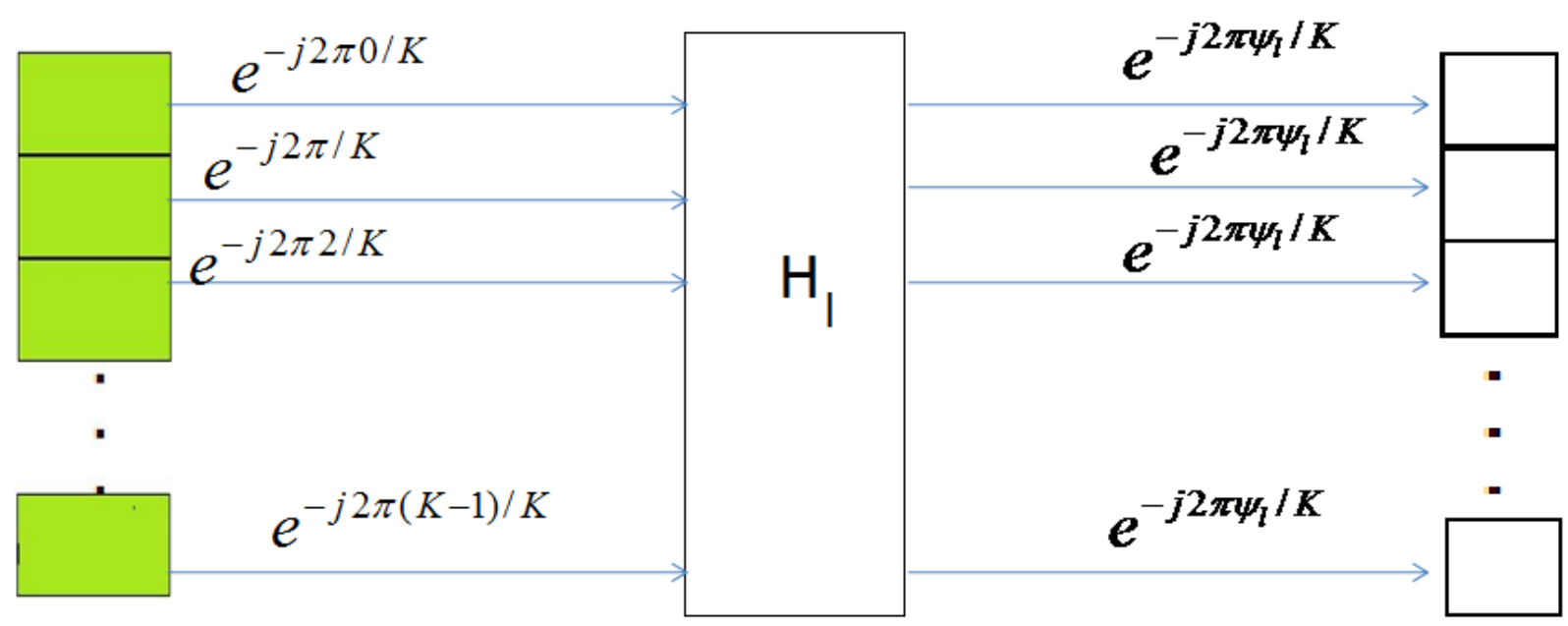

Figura 4.1: Rotação de fase aplicada sobre os coeficientes de $\mathbf{H}_{l}$ para o desvio de frequência de cada subportadora OFDM e ao instante de chegada $\psi_{l}$

A matriz $\mathbf{S}=\mathbf{S}(\mathbf{X})$ independe do valor dos coeficientes do canal, estando apenas relacionada com o símbolo $\mathbf{X}$ transmitido, a quantidade e o instante de chegada de cada um dos $L$ multipercursos resolvíveis.

Conhecendo-se o instante de chegada dos multipercursos, dado que foi transmitida um símbolo $\mathbf{X}$ qualquer, espera-se receber no receptor uma versão do símbolo $\mathbf{S}$ degradada pelos efeitos do canal. Por esse motivo, $\mathbf{S}$ é chamado de pseudo-símbolo, pois é sobre $\mathbf{S}$ que se baseará o critério de decisão no receptor.

Se o símbolo $\mathbf{X}$ transmitido estiver limitado a um alfabeto finito de $\mathrm{K} 1$ símbolos $\mathbf{C}=\mathbf{C}_{i}$, para $i=0,1, \ldots, K 1-1$, então, segundo [36], um algoritmo de decisão baseado na medida de correlação entre o pseudo-símbolo transmitido e o símbolo recebido pode ser sintetizado na equação 4.7.

$$
\widetilde{\mathbf{S}}=\underbrace{(\arg \max )}_{\mathbf{X}=\mathbf{X}_{i}}\left(\mathbf{Y}^{H} \mathbf{S}_{i} \mathbf{S}_{i}^{H} \mathbf{Y}\right)
$$

Na Equação 4.7 nota-se que o símbolo estimado $\widetilde{\mathbf{S}_{i}}$ (e por consequência, $\widetilde{\mathbf{C}_{i}}$ ) é obtido por meio de uma busca exaustiva por todos os pseudo-símbolos possíveis. Para cada um dos símbolos é necessária uma medida de correlação obtida por meio de produtos matriciais de $\mathbf{S}_{i}$ (de dimensões $\left.N_{c} \times M_{T} L\right), \mathbf{Y}\left(N_{c} \times M_{R}\right)$, e suas respectivas inversas. Consequentemente o algoritmo de recepção tem sua complexidade variando linearmente com $K_{1}$ e exponencialmente com o número de subportadoras utilizadas.

No caso de transmissões OFDM, como o LTE, o número de subportadoras é, em geral, da ordem de centenas, o que pode tornar o processo de recepção extremamente custoso e, em muitos casos, inviável. Para contornar essa situação, foi proposta em [37] a técnica de codificação baseada 


\subsubsection{Codificação NCP baseado em grupos de subportadoras}

Esta técnica visa simplificar o processo de decodificação, substituindo a detecção de um símbolo OFDM inteiro pela detecção de números inteiros de grupos de subportadoras. A codificação NCP baseada em grupos de subportadoras (NCPG) divide um símbolo OFDM em $N_{g}$ grupos de $P$ subportadoras, conforme mostra a Equação (4.8).

$$
P=N_{g} / N_{c}
$$

Por conveniência, escolhe-se os grupos de forma tal que a p-ésima portadora do g-ésimo grupo seja a de índice $g+p N_{g}$. Para cada um dos grupos, o símbolo $\mathbf{X}_{g}$ transmitido será dado por:

$$
\mathbf{X}_{g}=\left[\begin{array}{lllll}
\mathbf{x}_{g} & \mathbf{x}_{g+N_{g}} & \mathbf{x}_{g+2 N_{g}} & \cdots & \mathbf{x}_{g+(P-1) N_{g}}
\end{array}\right]^{T}
$$

\subsubsection{Livro-Código}

O livro-código que conterá todo o alfabeto com os $K_{1}$ símbolos é formado a partir da seguinte regra:

$$
\mathbf{X}_{g, i}=\sqrt{P / M_{t}} \boldsymbol{\Phi}^{i} \mathbf{B}, \quad i=0,1, \ldots, K_{1}-1
$$

Na Equação (4.10), $\boldsymbol{\Phi}=\operatorname{diag}_{k=0}^{P-1}\left\{e^{j 2 \pi u_{k} / K 1}\right\}$, com os valores $0 \leq u_{k} \leq\left(K_{1}-1\right)$, otimizados segundo critério de otimização que garanta baixa correlação entre pseudo-símbolos distintos. A nésima coluna de B é igual a ((n-1)L+1)-ésima coluna da matriz de FFT com dimensões $P \times P$. Nesta construção $\boldsymbol{\Phi}$ tem por função minimizar a correlação entre palavras-código distintas, enquanto $\mathbf{B}$ visa atingir a unitariedade do pseudo-símbolo [37] - a motivação dessa restrição ficará mais clara na seção 4.4 .

Com as substituições feitas até aqui, vale reescrever a equação do símbolo recebido nas portadoras do grupo $g$ :

$$
\mathbf{Y}_{g}=\mathbf{S}_{g, i} \overline{\mathbf{H}}+\mathbf{W}_{g}
$$

em que, $\mathbf{S}_{g, i}=\left[\mathbf{X}_{g, i} \mathbf{D}_{g}^{\psi_{1}} \mathbf{X}_{g, i} \ldots \mathbf{D}_{g}^{\psi_{L-1}} \mathbf{X}_{g, i}\right]$ e $\mathbf{D}_{g}=\operatorname{diag} g_{p=0}^{P-1}\left\{e^{-2 j \pi(p+N g) / N_{c}}\right\}$ e os componentes de $\mathbf{W}_{g}$ representam o ruído para as portadoras presentes neste grupo.

Tomando-se, $\gamma_{g}=e^{-2 j \pi \frac{g}{N_{c}}}$ e $\mathbf{D}_{p}=\operatorname{diag}_{p=0}^{P-1}\left\{e^{-2 j \pi(p) / P}\right\}$, tem-se:

$$
\mathbf{D}_{g}=\gamma_{g} \mathbf{D}_{p}
$$

que por sua vez leva a

$$
\mathbf{S}_{g, i}=\mathbf{S}_{G, i} \boldsymbol{\Gamma}_{g}
$$

em que $\mathbf{S}_{G, i}=\left[\mathbf{X}_{g, i} \mathbf{D}_{p}^{\psi_{1}} \mathbf{X}_{g, i} \ldots \mathbf{D}_{p}^{\psi_{L-1}} \mathbf{X} g, i\right]$ e $\boldsymbol{\Gamma}_{g}=\operatorname{diag}_{l=0}^{L-1}\left\{\gamma_{g}^{l}\right\} \otimes \mathbf{I}_{M_{T}}$ (o símbolo $\otimes$ denota o produto matricial de Kronecker). 
Substituindo (4.13) em (4.11), resta:

$$
\mathbf{Y}_{g}=\mathbf{S}_{G, i} \boldsymbol{\Gamma}_{g} \overline{\mathbf{H}}+\mathbf{W}_{g}
$$

Na Equação (4.14), é possível perceber que $S_{G_{i}}$ é fator comum para todos os grupos, enquanto $\boldsymbol{\Gamma}_{g} \overline{\mathbf{H}}$ provoca apenas uma rotação de fase no canal e não altera a distribuição dos seus coeficientes, podendo ser interpretado como um pseudo-canal. Posto isso é possível fazer a recepção de todos os grupos utilizando o algoritmo análogo à Equação (4.7):

$$
\widetilde{\mathbf{S}}_{g}=\underbrace{(\arg \max )}_{\mathbf{X}_{G, i}}=\left(\mathbf{Y}^{H} \mathbf{S}_{G, i} \mathbf{S}_{G, i}^{H} \mathbf{Y}\right)
$$

\subsection{Códificação Diferencial}

A idéia principal por trás de códigos diferenciais é introduzir uma relação de codificação entre blocos transmitidos consecutivamente. O código transmitido em um determinado bloco de subportadoras é obtido recursivamente a partir do bloco transmitido no bloco imediatamente anterior.

Extrapolando a técnica de grupos da seção anterior, o símbolo recebido para o g-ésimo grupo a partir da Equação (4.1), dado que foi transmitido neste grupo o símbolo $\mathbf{X}_{g}$, é dado por

$$
\mathbf{Y}_{g}=\mathbf{H X}_{g}+\mathbf{n}_{g}
$$

em que $\mathbf{n}_{g}$ representa o ruído nas portadoras do grupo.

No g-ésimo grupo será transmitida um símbolo diferencial pertencente a um alfabeto de tamanho $K_{2}$, denotado por $\mathbf{x}_{g}$ e obtido através da seguinte regra:

$$
\mathbf{X}_{g}=\left\{\begin{array}{l}
\mathbf{I}_{M_{T}}, \text { se } g=0 \\
\mathbf{V}^{n} \mathbf{X}_{g-1}, \text { caso contrário }
\end{array}\right.
$$

em que $\mathbf{V}^{n}$ representa o n-ésimo símbolo diferencial em um alfabeto de cardinalidade $K_{2}(n=$ $\left.0,1, \ldots\left(K_{2}-1\right)\right)$. A matriz $\mathbf{V}$, semente do livro-código, deve ser construída de forma que garanta a unitariedade do símbolo transmitido - a codificação não deve amplificar ou atenuar o sinal transmitido - e a baixa correlação entre as palavras códigos. Deve-se garantir ainda a propriedade de grupo dos códigos unitários, i.e., para quaisquer $0 \geq m, n \geq K_{2}$ o produto $\mathbf{V}^{m} \mathbf{V}^{n}$ resulta em um símbolo permitido dentro do livro-código.

Um algoritmo de construção possível é dado por $\mathbf{V}=\operatorname{dia} g_{r=0}^{M_{T}-1}\left\{e^{j 2 \pi v_{r} / K 2}\right\}$, com os parâmetros $v_{k}, 0 \leq v_{k} \leq K_{2}-1$ sendo otimizados visando diminuir a correlação máxima entre duas palavras códigos distintas.

\subsubsection{Processo de Recepção}

Substituindo (4.17) em (4.16), para $g=1,2, \ldots N_{g}-1$ leva-se a

$$
\mathbf{Y}_{g}=\mathbf{H V}_{g} \mathbf{X}_{g-1}+\mathbf{N}_{g}
$$


Observando-se atentamente, nota-se, que o primeiro bloco em 4.17 não carrega informação, sendo usado para realizar o treinamento do canal. Assim, o símbolo estimado na recepção pode ser obtido do grupo 1 em diante por:

$$
\widetilde{\mathbf{X}}_{g}=\underbrace{(\arg \max t r)}_{n}\left(\mathbf{V}^{n} \mathbf{Y}_{g}^{H} \widetilde{\mathbf{X}}_{g-1}\right)
$$

\subsection{Codificação Híbrida}

O modelo analisado aqui, descrito em [38], propõe uma técnica de transmissão não coerente para sistemas MIMO-OFDM, baseada em dois estágios de codificação um NCPG e um diferencial. O intuito de se ter 2 estágios distintos é maximizar o número de símbolos possíveis sem comprometer o sistema ou o custo computacional do receptor. Além disso esta estratégia ajuda a combater os efeitos da saturação da BER geralmente observado em códigos diferenciais.

A codificação híbrida que junta os 2 códigos não coerentes apresentados até aqui é obtida a partir do símbolo conjunto $\mathbf{C}_{g}$. Dado por

$$
\mathbf{C}_{g}=\mathbf{C}_{n c h, g} \mathbf{C}_{d i f, g}
$$

onde,

$$
\mathbf{C}_{n c h, g, i}=\sqrt{P / M_{t}} \boldsymbol{\Phi}^{i} \mathbf{B}, i=0,1, \ldots, K_{1}-1
$$

e

$$
\mathbf{C}_{d i f, g, n}=\left\{\begin{array}{l}
\mathbf{I}_{M_{T}}, \text { se } g=0 \\
\mathbf{V}^{n} \mathbf{C}_{d i g, g-1}, \text { c.c. }
\end{array}\right.
$$

Por consequência, o resultado da multiplicação entre os símbolos gerados nos dois estágios pode ser reescrito como :

$$
\mathbf{C}_{g, i, n}=\sqrt{P / M_{T}} \boldsymbol{\Phi}^{i} \mathbf{B C}_{d i f, g-1}
$$

\subsubsection{Processo de Decodificação}

De acordo com as Equações (4.21) e (4.23), o sinal recebido para o g-ésimo grupo pode ser rescrito como:

$$
\mathbf{Y}_{g}=\mathbf{S}_{i} \mathbf{A}_{n, g} H+\mathbf{W}_{g}
$$

em que, $\mathbf{A}_{n}=I_{L} \otimes \mathbf{C}_{d i f, g, n}$. Na equação 4.24, nota-se que ambas as palavras códigos (não coerente e diferencial) estão bem definidas e separadas matematicamente, o que torna possível que possam ser decodificadas seqüencialmente no lado do receptor. 
A decodificação se dará primeiramente para a palavra código não coerente. Uma vez que $\mathbf{A}_{n}$ é unitária, a distribuição de $\mathbf{H}$ e de $\mathbf{A}_{n} \mathbf{H}$ é a mesma. Desta forma a decodificação GLRT (generalized likelihood ratio test) deduzida em [36] pode ser aplicada a $R_{g}$ :

$$
\widetilde{\mathbf{S}}_{g}=\underbrace{(\arg \max )}_{\mathbf{X}_{G, i}}=\left(\mathbf{Y}^{H} \mathbf{S}_{G, i} \mathbf{S}_{G, i}^{H} \mathbf{Y}\right)
$$

Tendo uma vez estimado o símbolo não coerente transmitido, se torna mais fácil decodificar a palavra código diferencial recebida. Para tal, é necessário tentar forçar a zero a contribuição em $R_{g}$ devido ao estágio não coerente de codificação. Neste caso, podemos fazer a operação nãocoerente inversa:

$$
\widetilde{\mathbf{Y}}_{g}=\sqrt{\frac{M_{t}}{P}} \widetilde{\mathbf{S}}_{i, e s t}^{H} \mathbf{S}_{i} \mathbf{A}_{n} \mathbf{H}+\mathbf{W}
$$

Se a palavra código $\widetilde{\mathbf{C}}_{n c h, g, e s t}$ houver sido estimada com correção, então, devido a unitariedade da pseudo palavra código ter-se-á que:

$$
\tilde{Y}_{g, e s t}=\sqrt{\frac{M_{T}}{P}} \mathbf{A}_{n} \mathbf{H}+\widetilde{\mathbf{W}}=\sqrt{\frac{M_{T}}{P}} \mathbf{A}_{V}^{n} \mathbf{R}_{g-1}+\mathbf{Z}_{g}
$$

Com a matriz de ruído $Z_{g}$, tendo seus elementos modelados por uma distribuição de uma variável aleatória gaussiana complexa com média 0 e variância 2. E a partir de (4.27), um receptor ML pode ser utilizado com a seguinte regra de decisão:

$$
\widehat{n}=\min _{q=0,1, \ldots K_{2}-1}\left\{\left\|\widetilde{\mathbf{R}}_{g, e s t}-\mathbf{A}_{V}^{q} \mathbf{R}_{g-1}\right\|\right\}
$$

A probabilidade de erro desde segundo estágio de deteç̧ão, desde que o estágio não coerente tenha sido recebido com correção é a mesma que seria casso esse sistema fosse puramente diferencial [38].

\subsection{Resultados de Simulação e Análise dos Códigos}

\subsection{Simulação e Resultados}

Os resultados mostrados nessa Seção foram obtidos simulando o downlink do LTE para uma banda de $10 \mathrm{MHz}$, com uma separação entre subportadoras de $15 \mathrm{KHz}$. Neste caso, segundo consta em norma do 3GPP, o número de portadoras deve ser igual a 600. Por este motivo, os grupos de subportadoras analisados devem ser divisores inteiros de 600. O objetivo das simulações desenvolvidas é estabelecer a influência que cada um dos parâmetros do sistema tem sobre os demais.

A técnica de codificação elucidada na seção anterior apresenta uma série de parâmetros a serem dimensionados pelo projetista do código: $P, K_{1}, K_{2}, M_{T}, M_{R}$, a taxa de código $\left(R \approx \frac{\log _{2}\left(K_{1} K_{2}\right)}{P}\right.$ bits/uso do canal). O objetivo desta seção é mostrar a relação que cada uma destas variáveis tem com as demais e com o desempenho do sistema e mostrar os custos e benefícios inerentes a um 
aumento (diminuição) de cada uma das grandezas relacionadas acima, considerando-se um sistema do tipo LTE.

A única hipótese feita do lado do receptor é que se conhece o número de multipercursos do sistema e o instante de chegada dos mesmos, sendo o livro-código calculado para essa situação de interesse.

Em um primeiro momento, simulou-se o sistema apenas sob o efeito da codificação não coerente, com o objetivo de se avaliar o comportamento deste estágio de codificação sob a influência dos diversos parâmetros. A grande restrição sobre o desenvolvimento deste livro-código reside na escolha do número de subportadoras por grupo. Quão menor for o valor de $P$, mais vantajoso será para o sistema, uma vez que a complexidade do receptor varia exponencialmente com o número de subportadoras por grupo. Contudo, se $P<M_{T} L$, o código falhará e não será possível receber o sinal com precisão. Além disso o grau máximo de diversidade do sistema só será atingido quando $P>2 M_{T} L$ [36]. Assim, aumentar $M_{T}$, embora permita ao projetista aumentar o grau de diversidade do sistema, pode exigir um acréscimo considerável em $P$ para que o sistema funcione satisfatoriamente e nem sempre será vantajoso, uma vez que a grande motivação desta forma de modulação-codificação é a minimização da complexidade do receptor. Ademais, fixada uma taxa de código $R=\left(\log _{2}\left(K_{1}\right) / P\right.$ ) (bits/uso do canal), o aumento em $P$ pode criar um livro-código muito extenso, aumentando ainda mais o custo de recepção. Em termos práticos, para $R=0.5$, ao se saltar de $P=8$ para $P=20$, o salto em $K_{1}$ será de 16 para 1024 palavras-código.

As diferentes curvas presentes na Figura 4.2, obtidas sob os parâmetros da Tabela 4.1 em um cenário do tipo macro suburbano, evidencia o comportamento deste código sob o efeito de diferentes multipercursos. A superioridade do código 2 sobre os outros dois, deve-se sobretudo ao fato de que, neste caso, $P>2 M_{T} L$ e atingiu-se o grau máximo de diversidade para este sistema. O desempenho bastante inferior do código 3 sobre os demais, pode ser explicado pelo fato de este código estar próximo da região onde esta técnica de modulação falhará.

Tabela 4.1: Parâmetros dos Livros-Códigos para a figura 1

\begin{tabular}{|c|c|c|c|c|c|c|c|}
\hline & $P$ & $K 1$ & $L$ & $M_{T}$ & $M_{R}$ & $R \approx$ & $2 M_{T} L$ \\
\hline \hline Cod1 & 8 & 16 & 4 & 1 & 2 & 0.5 & 8 \\
\hline \hline Cod2 & 8 & 16 & 3 & 1 & 2 & 0.5 & 6 \\
\hline Cod3 & 8 & 16 & 3 & 2 & 2 & 0.5 & 12 \\
\hline
\end{tabular}

Na Figura 4.3, apresenta-se o comportamento do código 2 da tabela 4.1, sob os rês diferentes tipos de cenários propostos pelo modelo do 3GPP: micro urbano, macro urbano, macro suburbano. Comparando os resultados desta figura, nota-se que, em nenhum dos 3 cenários simulados, o desempenho do código se distanciou dos demais e em todos eles foi possível realizar uma deteç̧ão com certo grau de satisfatoriedade. Desta forma, concluiu-se que esta técnica funciona independentemente distribuição do perfil de potência de atraso (PDP).

Ainda tentando estimar o efeito do desvanecimento sobre cada uma das técnicas separadamente, realizaram-se simulações envolvendo apenas o estágio diferencial de codificação. Para esta 


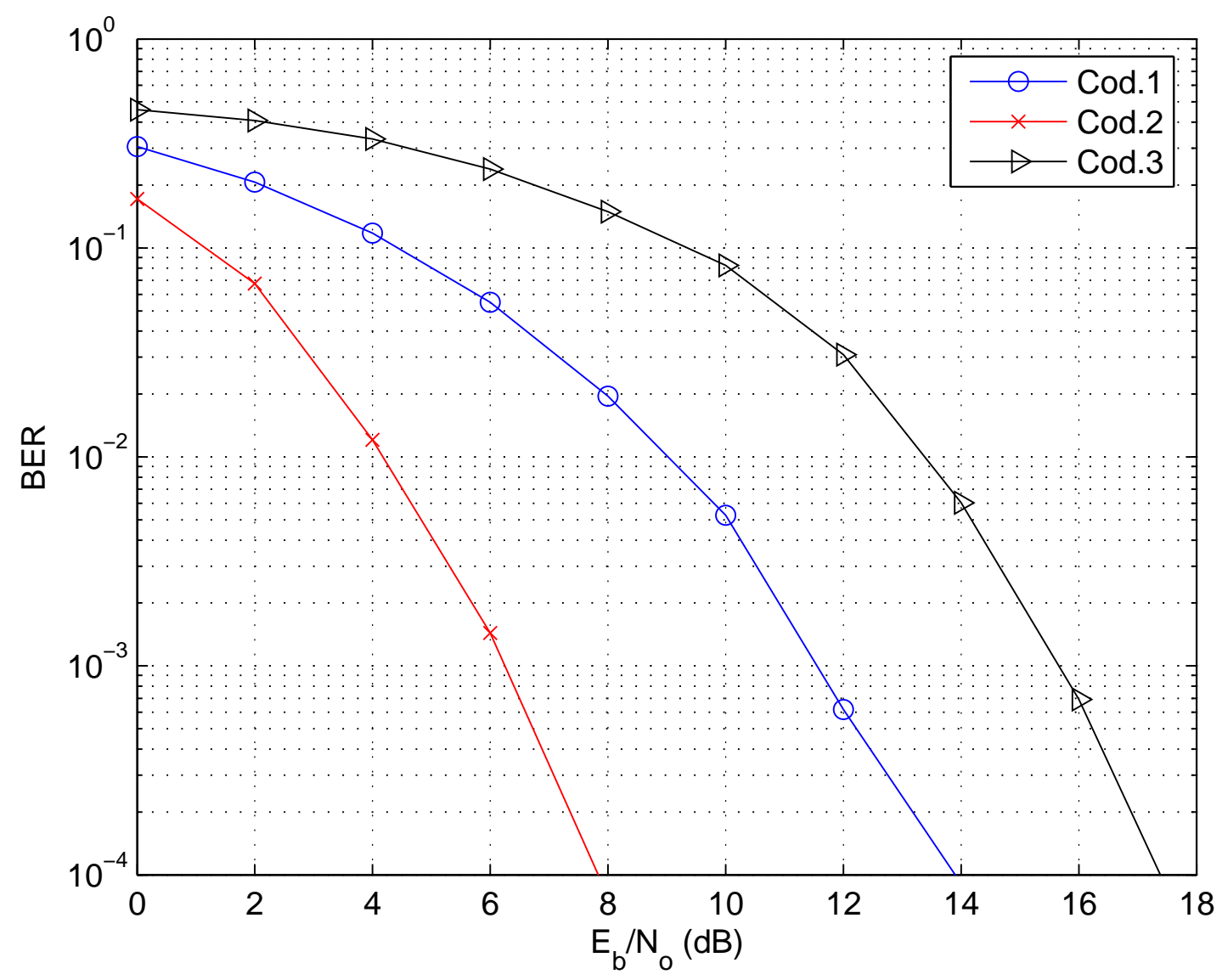

Figura 4.2: Comparação de performance da BER para a tabela 1.

segunda técnica, uma vez que a palavra-código tem dimensões $M_{T} \times M_{T}$, a escolha do número de subportadoras por grupo não apresenta qualquer restrição para o projetista, pois não tem qualquer influência na correlação entre palavras códigos distintas. Em linhas gerais, para este estágio de codificação diferencial, sabe-se que um acréscimo em $M_{T}$ melhora o desempenho do código para um livro código de tamanho $K_{2}$ fixado. Neste ponto, o projetista cai em uma solução de compromisso: um acrécimo em $M_{T}$ permite melhor desempenho da codificação diferencial e um aumento de diversidade na codificação não coerente, mas pode apresentar um custo muito elevado em termos de complexidade computacional.

Os resultados obtidos para a codificação diferencial foram obtidos com o código proposto na tabela 4.2 e estão presentes na Figura 4.4, onde se compara o desempenho deste código em diferentes cenários. Na figura 4.4 nota-se que o desempenho do receptor varia conforme o canal seja mais ou menos seletivo, de acordo com a PDP deste canal. Para os três tipos de ambientes de propagação - macro urbano, micro urbano e macro suburbano - a média de dispersão temporal máxima corresponde, respectivamente a 1,8229 $\mu s, 0,5924 \mu s$ e 0,423 $\mu s$, ao longo de diversas realizações do canal, sendo a dispersão temporal máxima do canal macro urbano a principal explicação encontrada para o desempenho ruim desta codificação quando comparada com as demais.

A última simulação realizada, presente na Figura 4.5, mostra o desempenho da técnica híbrida proposta na seção anterior. Neste caso escolheu-se um livro código com os parâmetros da tabela 4.3, 


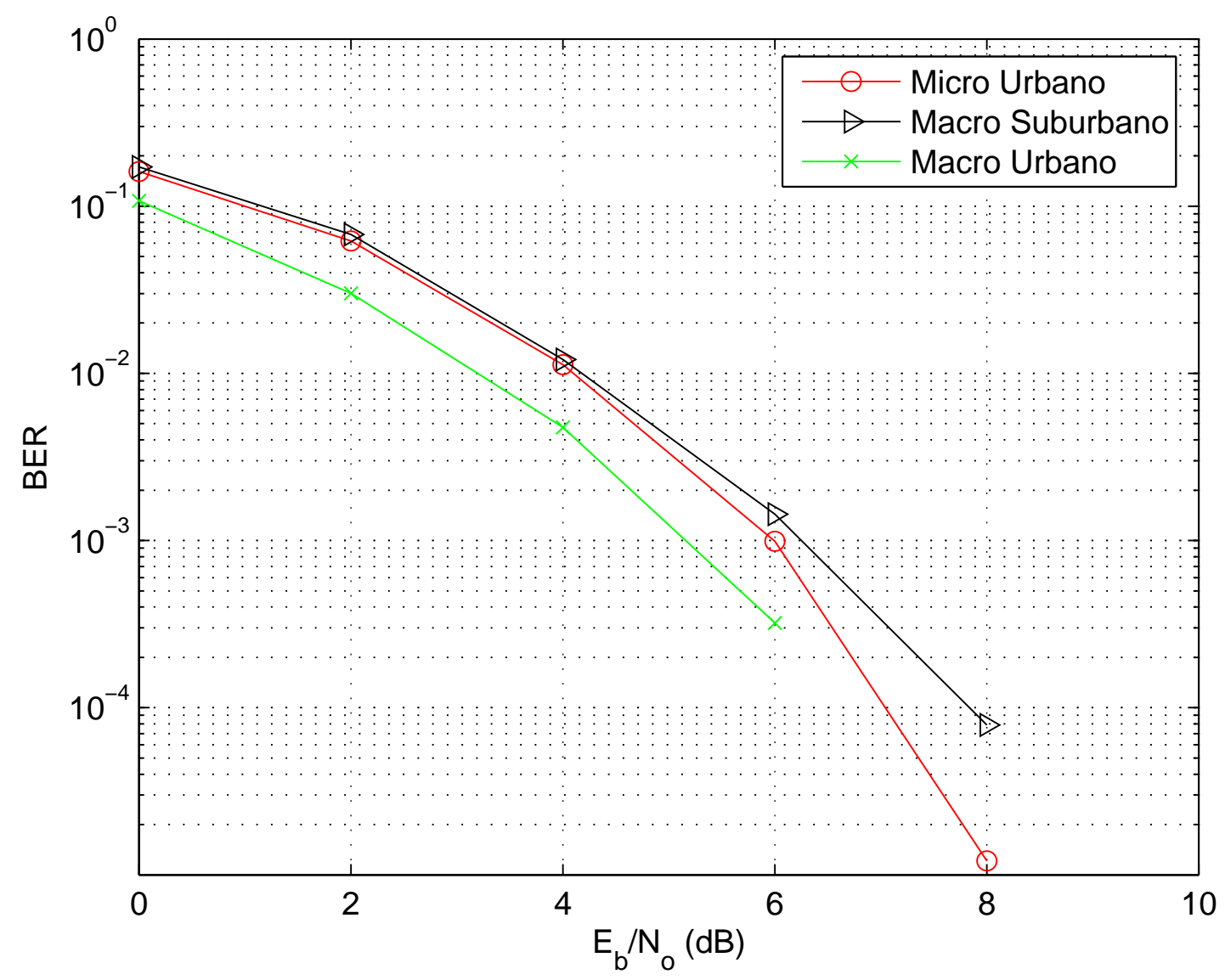

Figura 4.3: Comparação da performance da BER para o código 2 em diferentes cenários

Tabela 4.2: Parâmetros dos Livros-Códigos para a codificação Diferencial

\begin{tabular}{|c|c|c|c|c|c|c|c|}
\hline & $P$ & $K 2$ & $L$ & $M_{T}$ & $M_{R}$ & $R \approx$ & $2 M_{T} L$ \\
\hline \hline Cod4 & 8 & 16 & 3 & 1 & 2 & 0.5 & 16 \\
\hline \hline
\end{tabular}

para o perfil macro suburbano. O resultado mostra um resultado satisfatório do código proposto, uma vez que é possível atingir uma BER razoável (inferior a $10^{-5}$ ) para valores razoáveis de $E_{b} / N_{0}$. Observando conjuntamente este gráfico e a Tabela 4.3, nota-se que o acréscimo de uma antena transmissora de fato melhora o desempenho do código em termos de BER (permitindo inclusive maior número de palavras códigos no estágio diferencial) a curva do código 6 tem resultado melhor que a do código 5, mas o aumento de $P$ requerido pelas restrições de projeto compromete a taxa de código. Muitas vezes, será mais compensador aumentar o número de antenas receptoras em vez de antenas transmissoras, para melhorar a BER do sistema.

Ainda observando este gráfico, nota-se que mesmo aumentando o número de multipercursos este código continua apresentando bom desempenho. Em geral, maiores valores de $L$ permitem ganho de diversidade e um melhor desempenho do código, contudo comprometem a escolha de $P$ e, consequentemente, o custo do receptor. 


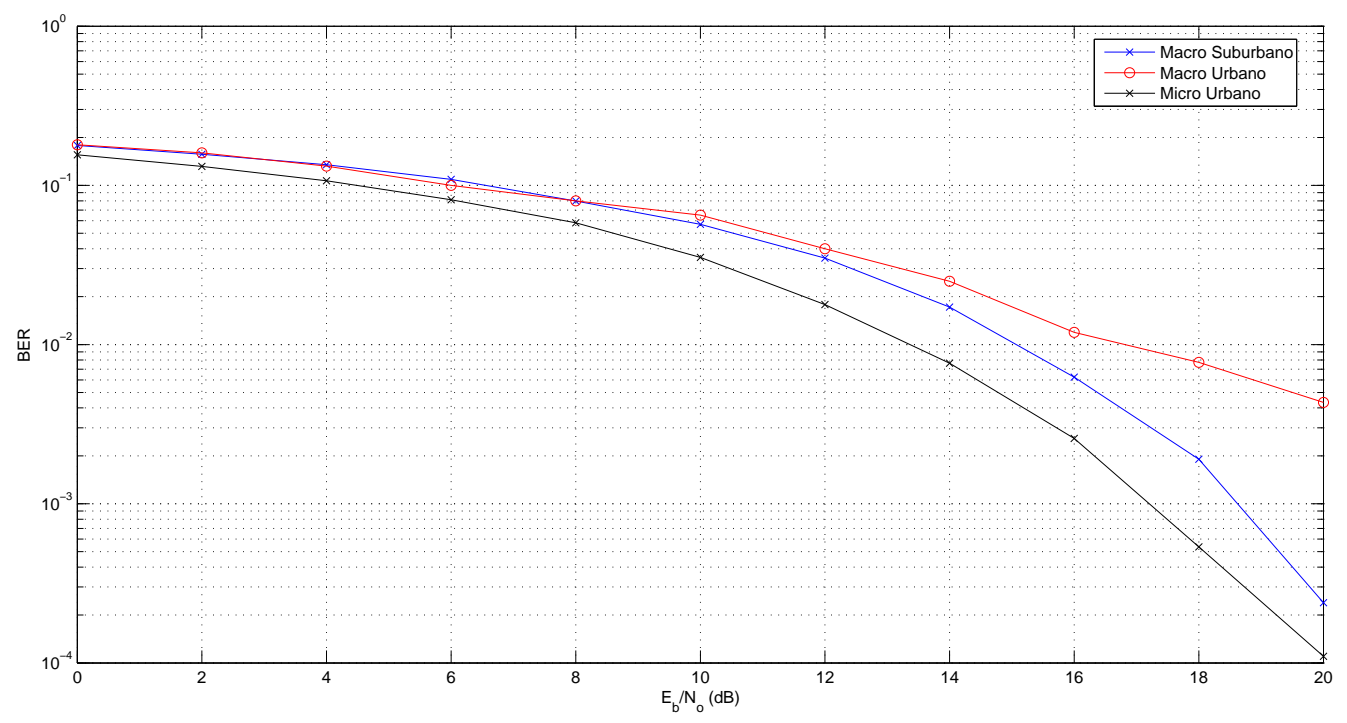

Figura 4.4: Comparação da performance da BER para a tabela 2

Tabela 4.3: Parâmetros dos Livros-Códigos para a técnica híbrida

\begin{tabular}{|c|c|c|c|c|c|c|c|}
\hline & $P$ & $\mathrm{~L}$ & $K 1$ & $K 2$ & $M_{T}$ & $M_{R}$ & $R \approx$ \\
\hline \hline Cod5 & 15 & 7 & 1024 & 16 & 1 & 2 & 0.9333 \\
\hline \hline Cod6 & 30 & 7 & 1024 & 64 & 2 & 2 & 0.5333 \\
\hline \hline
\end{tabular}

\subsection{Comparação entre Códigos Coerentes e Não Coerentes}

Devido a recepção independente de estimação dos códigos não coerentes, espera-se que este tenham desempenho melhor que os códigos coerentes nos casos em que, para esse último, a estimação do canal no receptor e/ou transmissor é ruim. Uma situação que compromete a qualidade dessa estimação é a alta mobilidade do terminal móvel, o que sempre dificultou a obtenção de altas taxas de transmissão sob essa condição. Como não realizam codificação de canal os códigos não coerentes se apresentam como uma possível solução que ajude a contornar este obstáculo.

Na Figura 4.6, buscou-se avaliar o desempenho da técnica híbrida proposta neste capítulo, do SBFC proposto para o LTE e da técnica de divisão em paralelo dos canais MIMO (ver Capítulo 3). Nesta simulação, utilizou-se o Código 5 tanto para $M_{R}=2$ como para $M_{R}=4$ e uma velocidade do móvel corresponde a $120 \mathrm{Km} / \mathrm{h}$.

A primeira consideração a fazer sob essa comparação é que, para a técnica híbrida proposta, aumentar o número de antenas receptoras, melhora o desempenho do sistema por um aumento no grau de diversidade, sem comprometer a eficiência espectral estabelecida pelos parâmetros $K_{1}, K_{2}$ e $P$. Para a decomposição em valores singulares aumentar $M_{R}$ sem acréscimo em $M_{T}$ não representa ganhos tão significativos, pois o posto máximo de $\mathbf{H}$ será igual ao máximo entre $M_{R}$ e $M_{T}$. Para o SBFC, adotado pelo LTE, é possível aumentar o número de antenas receptoras de dois para 


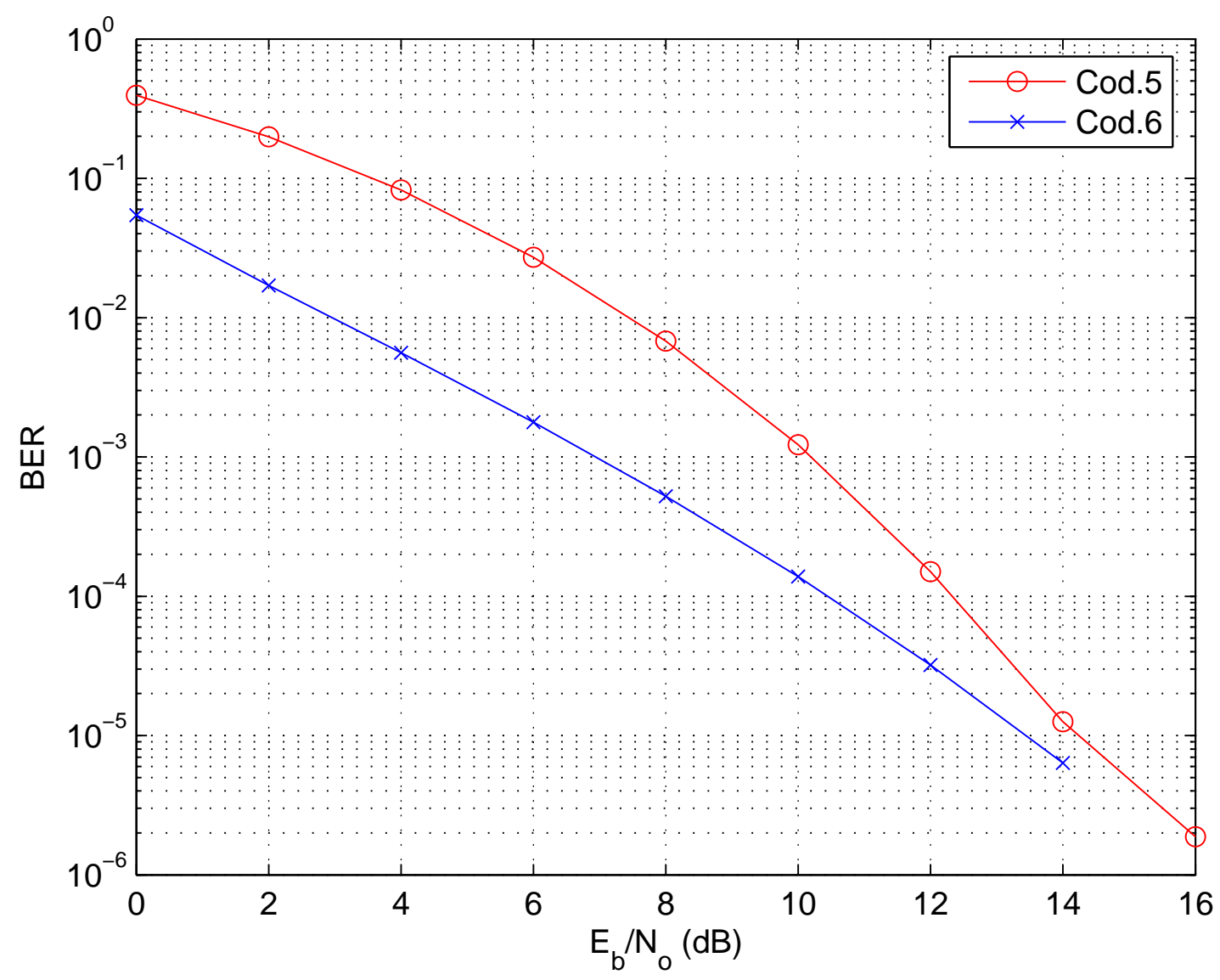

Figura 4.5: Comparação da performance da BER para a tabela 3

quatro, mas isso corresponde a aumentar o número de antenas transmissoras ou a uma perda na eficiência especral; aumentos maiores em $M_{R}$ exigem, em contrapartida com a maior diversidade, uma perda na eficiência especral do sisema. Nesse sentido, como o LTE-A prevê um arranjo de aé 8 antenas no receptor (e no transmissor), o código não coerente se mostra, em termos de diversidade, o mais flexível para trabalhar com diferentes valores de $M_{R}$ sem comprometer a eficiência espectral pré-estabelecida.

Ouro resultado que se vê é que para $M_{R}=2$ o desempenho em taxa de erro de bit dos códigos coerentes é superior ao da técnica híbrida proposta. Entretanto, como permite maior flexibilidade em termos do número de antenas receptoras o código não coerente com $M_{R}=4$ apresenta maior grau de diversidade e, consequentemente, melhor desempenho de BER. Contudo, estes códigos tem como característica a dificuldade em oferecer elevada eficiência espectral. Apesar do melhor desempenho de BER neste caso, a taxa de transmissão oferecida pelo código 5 é de 0,933 bits por portadora, consideravelmente inferior aos 2 bits por portadora atingido pelo SFBC com a modulação QPSK. Essa difereneça na taxa de transmissão, não compensa os 9,5\% recursos do sistema perdidos em função do envio de pilotos no caso do LTE (para $M_{T}=2$ ). 


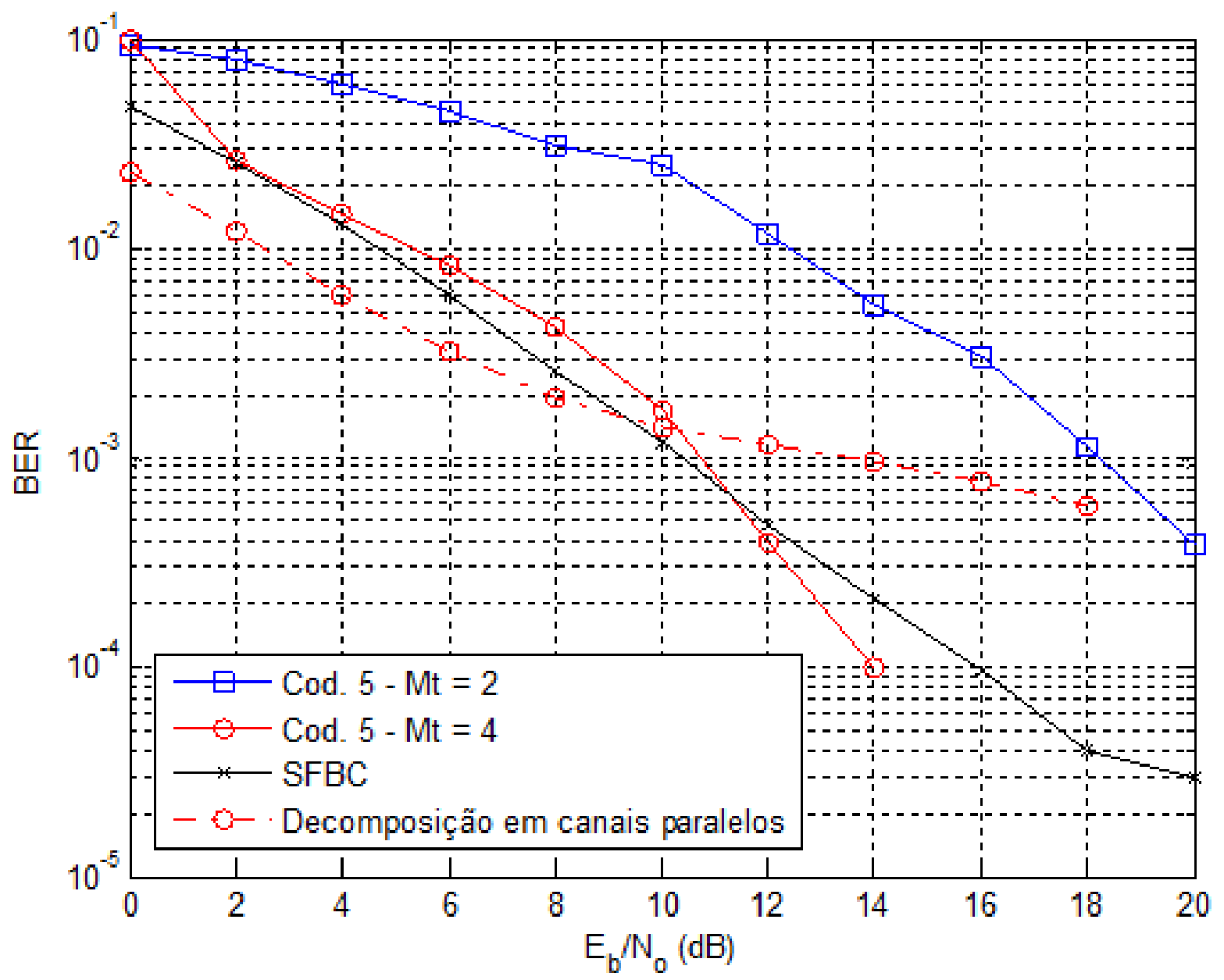

Figura 4.6: Comparação da performance da BER para a Tabela 4

\subsection{Conclusões}

Neste Capítulo foram vistas as relações de trade-off entre os parâmetros de projeto para a construção de um código SF unitário baseado em grupos, aplicado ao LTE. Entre outras coisas, conclui-se que, em determinados tipos de cenário, a técnica proposta tem bom desempenho e pode servir como opção a um esquema de transmissão MIMO que exige menor complexidade do receptor que um sistema coerente.

As técnicas propostas exploram alguns dos pontos que estão por trás do LTE desde o início de sua padronização pelo $3 \mathrm{GPP}$ : arquitetura simplificada, baixo consumo de energia (por exigir pouco processamento). Em contrapartida, viu-se que para se obter eficiência espectral muito elevada seria necessário aumentar a complexidade computaciona do receptor. Para que esta especificação seja atendida, seria necessário encontrar novas formas de se executar a recepção do sistema, como se sugere em [37].

Diferentes observações são feitas ainda a respeito da interdependência entre os fatores de projeto: um aumento no número de multipercursos resolvíveis ou de antenas transmissoras pode fornecer um aumento no grau de diversidade do sistema, contudo este ganho se dá a custa de 
um aumento exponencial na complexidade do receptor. Avalia-se também que o número de multipercursos pode aumentar o grau de diversidade do sistema, mas criar uma restrição forte sobre o número de subportadoras por grupo, devido ao estágio de codificação puramente não coerente, o que pode comprometer o custo do receptor. Ademais, nota-se que o desempenho do estágio diferencial é severamente afetado pelo comportamento do canal, não sendo aplicável em alguns cenários reais. Nestas situações, entretanto, pode-se permanecer com a codificação puramente não coerente.

Outro fator que merece destaque é que os códigos não coerentes permitem a adoção de valores crescentes de $M_{R}$ aumentando a diversidade do sisema sem compromeer a eficiência espectral préestabelecida. Viu-se ainda que esses códigos tem desempenho relativamente bons para ambientes de alta mobilidade; estes códigos mostram-se, portanto, como uma possível alernativa para os sistemas 4G. O desempenho desta técnica pode ainda ser ajustado, dentro de certas limitações, com diferentes escolhas de seus parâmetros $K_{1}, K_{2}, M_{T}$ e $P$. Entretanto, só é vantajoso empregar o código híbrido proposto para valores não muito elevados de multipercursos resolvíveis, pois, caso contrário, o número de subportadoras por grupo cresce demasiadamente e o sistema estará comprometido ou em eficiência espectral ou em complexidade do receptor. 


\section{Capítulo 5}

\section{Conclusões e Sugestões para Trabalhos Futuros}

Ao longo deste estudo, foram analisadas diferentes estratégias de transmissão MIMO aplicadas ao enlace direto do LTE. Configurações com múltiplas antenas tem sido muito estudados como métodos para se aumentar a eficiência espectral do sistema e minimizar a taxa de erro de bit.

Contudo, a maioria dos sistemas MIMO propostos necessitam de uma estimação precisa do canal físico, e fazem certas inferências sobre o tempo (ou banda) de coerência desse sistema. Viuse, em especial no Capítulo 3, que estes sistemas podem experimentar uma certa degradação em seus desempenhos em algumas situações que envolvem erro de estimação do canal, ou um canal bastante variante com o tempo. Sistemas que usam precodificadores baseados na qualidade da estimação podem ainda apresentar desempenhos falhos em termos de taxa de erro de bit, devido ao atraso do conhecimento da estimação inerente a latência do sistema.

Como solução alternativa, foram propostos sistemas de codificação não coerente que recebem o sinal transmitido sem executar a estimação do canal. Ao longo deste trabalho, foram estudadas as relações de trade-off entre os parâmetros de projeto para a construção de um destes códigos unitário baseado em agrupamentos de subportadoras. Conclui-se do estudo supracitado que um aumento no número de multipercursos resolvíveis ou de antenas transmissoras pode fornecer um aumento no grau de diversidade do sistema melhorando o desempenho da BER, contudo este ganho se dá a custa de um aumento exponencial na complexidade do receptor. Caso se consiga estabelecer métodos alternativos de recepção que simplifiquem o processo de decodificação este sistema pode trazer ganhos consideráveis para um sistema MIMO-OFDM.

Viu-se também que o número de multipercursos pode aumentar o grau de diversidade do sistema, mas criar uma restrição forte sobre o número de subportadoras por grupo, devido ao estágio de codificação puramente não coerente, o que pode comprometer o custo do receptor. Além disso, nota-se que o desempenho do estágio diferencial é severamente afetado pelo comportamento do canal, não sendo aplicável em alguns cenários.

Comparando-se, enfim, as técnicas não coerentes e coerentes viu-se que a primeira tem a vantagem de simplificar o algoritmo de recepção. Contudo, na maioria dos casos, estes sistemas ap- 
resentam uma menor eficiência espectral - dependendo da complexidade que se permite atingir no receptor e do número de multipercursos. Mostra-se, consequentemente, que existe um compromisso entre a complexidade e robustez do receptor e a eficiência espectral em função do conhecimento do canal.

Vale, contudo, ressaltar, que a adoção da técnica híbrida proposta depende do número de multipercursos resolvíveis. Se este número for elevado, então ou a complexidade do receptor ou a eficiência espectral estarão comprometidos.

Visando uma continuidade do tema pesquisado, sugere-se algumas abordagens para trabalhos futuros, que ajudem a discutir a viabilidade dos códigos não coerentes para casos reais. São elas:

- Implementação de codificadores de canal para os códigos não coerentes, com o objetivo de verificar como eles se comportam em relação às técnicas coerentes com o código turbo.

- Implementação da ferramenta proposta em [37] que ajuda a minimizar a complexidade do receptor, permitindo aumento na taxa de código do sistema. 


\section{REFERÊNCIAS BIBLIOGRÁFICAS}

[1] ASTELY, D.; AL. et. Lte: The evolution of mobile broadband. IEEE Communications Magazine, p. pp. 44-51, April 2009.

[2] GOLDSMith, A. C. A. P. A. MIMO Wireless Communications. First. [S.l.]: Cambridge University Press, 2007.

[3] SESIA I. TOUFIK, M. B. S. LTE - The UMTS Long Term Evolution: From theory to practice. First. [S.l.]: John Wiley \& Sons, 2009.

[4] ANATEL. Dados de Acessos Móveis em Operação e Unidade da Federação. Disponível em: < ftp://ftp.3gpp.org/Inbox/2008_ web_ files/LTA_ Paper.pdf > . Acessado em abril de 2009., abril de 2009.

[5] 3GPP. Evolved Universal Terrestrial Radio Access (E-UTRA) and Evolved Universal Terrestrial Radio Access Network (E-UTRAN); Overall description; [S.l.], 2008.

[6] 3GPP. Third Generation Partnership Project Agreement. [S.l.], 1998.

[7] 3GPP. Partnership Project Description. [S.l.], 1998.

[8] AL, D. A. et. A future radio-access framework. IEEE JSAC, v. 24, Março de 2006.

[9] 3GPP. LTE-ADVANCED. [S.1.], 2008.

[10] WINNER. Assessment of Advanced Beamforming and MIMO Technologies. [S.1.], 2005.

[11] 3GPP. UTRA-UTRAN Long Term Evolution (LTE) and 3GPP System Architecture Evolution (SAE). Disponível em: < ftp://ftp.3gpp.org/Inbox/2008_ web_ files/LTA_ Paper.pdf > . Acessado em maio de 2009.

[12] DAHLMAN, e. a. E. The 3g long-term evolution - radio interface concepts and performance evaluation. In: Vehicular Technology Conference, VTC 2006-Spring IEEE 63rd. [S.1.: s.n.].

[13] LIU, H.; LI, G. OFDM-Based Broadband Wireless Networks: Design and Optimization. First. [S.l.]: John Wiley \& Sons, 2005.

[14] OCHIAI, H.; IMAI, H. Performance analysis of deliberately clipped ofdm signals. IEEE Trans. Commun., vol. 50, p. pp. 89-101, Jan. 2002.

[15] UliAn, I. A. Trabalho de Conclusão de Curso: Análise dos Efeitos da Não Linearidade do Amplificador no Desempenho de um Sistema OFDM. Apresentado em julho de 2009. 
[16] 3GPP. Evolved Universal Terrestrial Radio Access (E-UTRA); Physical Channels and Modulation. [S.1.], 2008.

[17] 3GPP. Evolved Universal Terrestrial Radio Access (E-UTRA); Multiplexing and Channel Coding. [S.1.], 2008.

[18] MOON, T. K. Error Correction Coding: Mathematical Methods and Algorithms. First. [S.1.]: John Wiley \& Sons, 2005.

[19] BERROU, C.; GLAVIEUX, A. Near optimum error correcting coding and decoding: Turbo codes. IEEE Trans. Commun., vol. 44, p. pp. 1261-1271, October 1996.

[20] BERROU, A. G. C.; THITIMAJSHIMA, P. Near shannon limit error-correcting coding and decoding: Turbo codes. In: IEEE International Conference on Communications. Geneva,Switzerland: [s.n.], 1993. p. 1064-1070.

[21] YAFENG, Z. L. W.; DACHENG, Y. Performance analysis of type iii harq with turbo codes. In: Vehicular Technology Conference, 2003. VTC 2003-Spring. The 57th IEEE Semiannual. [S.1.: s.n.], 2003. v. 4, p. 2740-2744.

[22] FOSCHINI, G. J.; GANS, M. J. On limits of wireless communication in a fading environment when using multiple antennas. Wireless Pers. Commun., vol. 6, p. pp. 311Ú335, Mar. 1998.

[23] GUEY, J. et al. Signal design for transmitter diversity wireless communication systems over rayleigh fading channels. In: Vehicular Technology Conference, VTC, IEEE. [S.l.: s.n.], 1996. p. pg 136-140.

[24] TSE, D.; VISWANATH, P. Fundamentals of Wireless Communication. First. [S.l.]: Cambridge University Press, 2004.

[25] GIANNAKIS ZHIQIANG LIU, X. M. G. B.; ZHOU, S. Space-Time Coding for Broadband Wireless Communications. Primeira edição. [S.l.]: Cambridge University Press, 2007.

[26] WETZKER, G. Definition of spatial multiplexing gain. Electronics Letters, vol. 41, p. pp. 311 Ü 335, Maio 2005.

[27] KALtenBerGer M. KOUNTOURIS, D. G. F.; KNOPP, R. Correlation and capacity of measured multi-user mimo channels. In: IEEE International Symposium on Personal, Indoor and Mobile Radio Communications. [S.1.: s.n.], 2008.

[28] KO, S.-W.; KIM, S.-L. Block waterfilling with power borrowing for multicarrier communications. In: Vehicular Technology Conference, VTC Fall. IEEE 68th. [S.l.: s.n.], 2008. p. pg $1-5$.

[29] ALAMOUTI, S. M. A simple transmit diversity technique for wireless communications. IEEE Journal on Select Areas in Communications, p. pp 1451-1458, Outubro 1998.

[30] 3GPP. patial Channel Model for Multiple Input Multiple Output (MIMO) Simulations. [S.1.], 2003. 
[31] SALO, e. a. J. MATLAB implementation of the 3GPP Spatial Channel Model. [S.1.], 2005.

[32] LI, J. C. Y.; SOLLENBERGER, N. Transmitter diversity for ofdm systems and its impact on high-rate data wireless networks. IEEE Journal on Selected Areas in Communications, p. pp. 1233Ü1243, Julho de 1999.

[33] LEI, e. a. H. Downlink dynamic resource allocation for multi-cell ofdma system. em: Vehicular technology conference. In: Vehicular Technology Conference, 2003. VTC 2003-Fall. The 58th IEEE Semiannual. [S.l.: s.n.], 2003. p. 1698 Ü 1702.

[34] LAU., V. Proportional fair space-time scheduling for wireless communications. Communications, IEEE Transactions, p. p. 1353 Ü 1360, 2005.

[35] LETAIEF, K. Y. J. Z. Dynamic multiuser resource allocation and adaptation for wireless systems. Wireless Communications, IEEE., p. p. 38Ü 47, 2006.

[36] BöLCKSEI, M. B. e H. Noncoherent space-frequency coded mimo-ofdm. IEEE Journal on Selected Areas in Communications, p. pp.1799-1810, Setembro de 2005.

[37] LI LI, H. e. T. K. Q. Group-based noncoherent space-frequency codes and efficient decoding. In: Vehicular Technology Conference, VTC 2008-Spring IEEE. [S.1.: s.n.], 2008. p. pg 595-599.

[38] LI LI, H. e. T. K. Q. Noncoherent space-frequency codes for broadband mimo systems over frequency-selective fading channels. In: Vehicular Technology Conference, VTC 2008-Spring IEEE. [S.1.: s.n.], 2008. p. pg 554-558. 
ANEXOS 